\title{
DEDUCTION OF ATTORNEYS' FEES FOR FEDERAL INCOME TAX PURPOSES*
}

\section{Donald McDonald $\dagger$}

When you bill a client for your legal services, he may well ask, "Is this fee deductible in computing my income tax?" The answer is not always easy. The permissible income tax benefit varies widely.

The fee may have been for services wholly personal, and therefore in no way deductible. It may have to be added to the cost of an asset. If the asset is non-depreciable, the fee becomes deductible only when the asset is sold or abandoned. If the asset is subject to exhaustion, there will be an annual tax benefit through depreciation, amortization, or depletion. If your fee is immediately deductible, it may reduce ordinary income by the full amount, or it may only reduce a capital gain or increase a capital loss. One fee covering several types of service may have to be divided and the parts deducted in different ways.

\section{General Principles}

To be deductible attorneys' fees must be for a service qualifying as a deduction under some section of the Internal Revenue Code, ${ }^{1}$ without

* This Article will discuss the following matters:

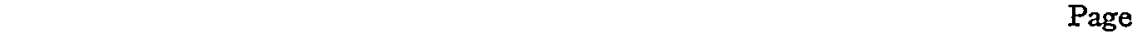

General Principles $\ldots \ldots \ldots \ldots \ldots \ldots \ldots \ldots \ldots \ldots \ldots \ldots \ldots \ldots \ldots \ldots \ldots . \ldots \ldots$

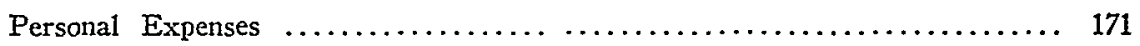

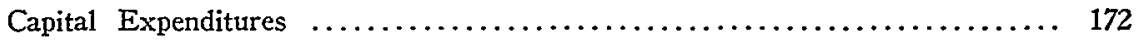

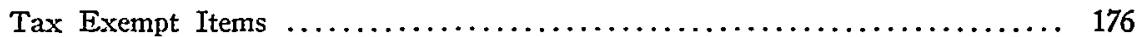

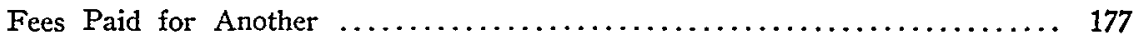

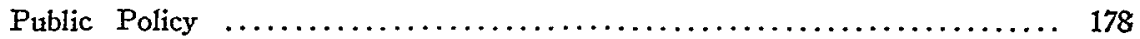

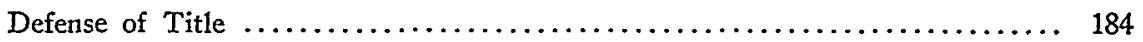

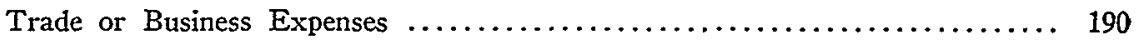

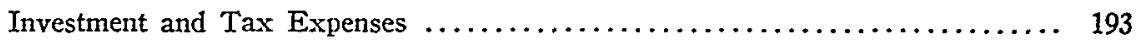

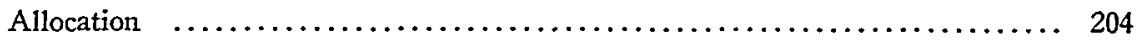

† A.B., 1939, LL.B., 1942, Harvard University. Member of the Philadelphia, Pennsylvania and Nebraska Bars. Secretary, Committee on Taxation, Philadelphia Bar Association.

1. E.g., Deputy v. du Pont, 308 U.S. 488 (1940). 
falling afoul of either statutory ${ }^{2}$ or non-statutory ${ }^{3}$ proscriptions.

Since 1913, the income tax laws have allowed a full deduction against ordinary income for all the ordinary and necessary expenses in carrying on any trade or business, including a reasonable allowance for compensation for personal services actually rendered. ${ }^{4}$ Since 1942 the Codes have allowed individuals a similar deduction for all the ordinary and necessary expenses for the production or collection of income, or for the management, conservation, or maintenance of property held for the production of income. ${ }^{5}$ The 1954 Code has made it clear that expense "in connection with the determination, collection, or refund of any tax" is fully deductible. ${ }^{\circ}$

Beyond these broad allowances, sums paid for legal services may increase deductions permitted under the Code and regulations for uninsured corporate losses ${ }^{7}$ or individual losses in trade, business, or transactions entered into for profit, ${ }^{8}$ for depreciation ${ }^{9}$ or depletion, ${ }^{10}$ or may reduce gain or increase loss by offsetting part of the selling price realized ${ }^{11}$ or increasing the adjusted basis. ${ }^{12}$

Lawyers' fees have had little difficulty generally in meeting the continued statutory requirement that expenses be "ordinary and neces-

2. In several sections, the Internal Revenue Code of 1954 flatly denies a deduction for specific expenses. Lawyers' fees often fall within this list. No deduction is allowed for :

(1) "personal, living, or family expenses," Internal Revenue Code of 1954, \$262, formerly INTERNAL REvENuE CODE OF 1939, §24(a) (1); (Hereafter the Internal Revenue Code of 1954, 68A Stat. 3 et seq. (1954), will be cited I.R.C.).

(2) "any amount paid out for new' buildings or for permanent improvements or betterments made to increase the value of any property or estate," I.R.C. $\$ 263$ (a) (1), formerly INT. REv. CoDE of 1939, $\$ 24(a)(2)$;

(3) "any amount expended in restoring property or in making good the exhaustion thereof for which an allowance is or has been made," I.R.C. $\$ 263(\mathrm{a})$ (2), formerly INT. REv. CODE of 1939, §24(a) (3);

(4) amounts allocable to tax exempt income (other than tax exempt interest received by a business), I.R.C. $\$ 265$, formerly INT. REv. CoDE of 1939, $\$ 24$ (a) (5) ; cf. I.R.C. $\$ 265(2)$ and INT. REV. CODE OF 1939, \$23(b).

3. E.g., fees paid for the benefit of another, contrary to public policy, or for the defense of title are not deductible. Edelmann, Non Trade or Non Business Expenses, 7 Ann. Inst. ON Fed. Taxation 965-77 (1949).

4. I.R.C. $\$ 162$ (a) (1), formerly INT. REv. CoDE of 1939, §23(a) (1) (A).

5. I.R.C. \$212, formerly INT. REv. CoDE of 1939, §23(a) (2).

6. I.R.C. $\$ 212(3)$ (italics added). While previously costs of determining many taxes had been deductible, the costs of determining gift taxes had not.

7. I.R.C. $\$ 165$ (a), formerly INT. Rev. CoDE of 1939, §23(f).

8. I.R.C. $\$ 165$ (c), formerly INT. REv. CODE of $1939, \S 23(\mathrm{e})$.

9. I.R.C. $\$ 167$, formerly INT. REv. CoDE of 1939, §23(1) (1).

10. I.R.C. $\$ 611$, formerly INT. Rev. CoDE of 1939, §23(m).

11. U.S. Treas. Reg. 118, $\$ 39.24$ (a)-2(a) (1953) ; cf. I.R.C. $\$ 1034$ (b).

12. I.R.C. $\S 1016(a)(1)$, formerly INT. REv. CoDE of 1939 , $\S 113$ (b) (1) (A). 
sary." 13 Justice Cardozo chose them as the natural illustration of the meaning of the words, when he said:

"Ordinary in this context does not mean that the payments must be habitual or normal in the sense that the same taxpayer will have to make them often. A lawsuit affecting the safety of a business may happen once in a lifetime. The counsel fees may be so heavy that repetition is unlikely. None the less, the expense is an ordinary one because we know from experience that payments for such a purpose, whether the amount is large or small, are common and accepted means of defense against attack." 14

If they are challenged as extraordinary or unnecessary, the payment will probably involve a question of business morality or public policy. ${ }^{15}$ Fees have been held necessary whether ${ }^{16}$ or not ${ }^{17}$ a lawsuit has been brought.

Both business ${ }^{18}$ and non-business ${ }^{19}$ expenses must be "reasonable" to be deductible. The Commissioner has seldom brought this issue to litigation, however, where attorneys' fees have been involved. ${ }^{20}$

The deduction is allowed for current expenses "paid or incurred during the taxable year." 21 If your client is on the cash basis, it makes no difference when you send him your bill. He gets his deduction, if any, when he pays. But if he is on the accrual basis, when the amount of the fee is undetermined and he has no arrangement with you that would allow him to make a reasonably accurate estimate of your charge, the deduction is allowed in the year the bill is sent, even though the services have been performed in a prior year. ${ }^{22}$

13. A requirement the American Law Institute would drop. Cf. 1 FederaL Income TAX StatuTe 268, \&X 151(b), comments (Feb. 1954 draft). The present law is closely examined on this point in Bruton, The Deductibility of Legal Expenses in Computing Income Tax, 3 S.C.L.Q. 107, 109-17 (1950).

14. Welch v. Helvering, 290 U.S. 111, 114 (1933).

15. For a general discussion of the influence of "public policy" see text beginning at note 116 infra; cf. Estate of Lashells, 11 CCH TC MEN. DEC. 274, 282 (1952); Tinkoff v. Commissioner, 120 F.2d 564 (7th Cir. 1941).

16. Kornhauser v. United States, 276 U.S. 145, 152 (1928).

17. Waldo Salt, 18 T.C. 182,186 (1952).

18. I.R.C. $\$ 162(a)(1)$.

19. Sen. Rep. No. 1631, 77th Cong., 2d Sess. 88 (1942), 1942-2 Cunr. Bull. 504, 571 and H.R. REP. No. 2333, 77th Cong., 2d Sess. 75 (1942), 1942-2 CuM. BuLs. 372, 430 state: "Expenses, to be deductible under Sec. 23 (a) (2) must be ordinary" and necessary, which rule presupposes that they must be reasonable in amount. . . ."

20. In Indialantic, Inc., $12 \mathrm{CCH}$ TC MEM. DEc. 880 (1953), a deduction for a $\$ 50,000$ fee was cut to $\$ 17,500$, rev'd and remanded, 5 CCH 1954 FED. TAX REP. If 9629 (6th Cir.).

21. I.R.C. \$162(a).

22. The Cold Metal Process Co., 17 T.C. 916 (1951), aff'd, 1 CCH 1953 TAx CT. REP. T 9135 (6th Cir. 1952) ; cf. Kanne v. American Factors, Ltd., 190 F.2d 155, 160-61 (9th Cir. 1951). 


\section{Personal Expenses}

No deduction is allowed for payments for legal services in primarily personal matters. ${ }^{23}$ Much of the general practitioner's work is of this kind, including the preparation of wills; ${ }^{24}$ the prosecution or defense of actions to recover damages for personal injuries, ${ }^{25}$ for destruction or seizure of non-income producing property, ${ }^{26}$ for libel ${ }^{27}$ or slander, ${ }^{28}$ or for breach of promise ${ }^{29}$ or the prosecution or defense of actions for separation or divorce, ${ }^{30}$ for the commitment ${ }^{31}$ or release of an incompetent, ${ }^{32}$ or to secure a release from the armed forces. ${ }^{33}$

Other expenses held to be personal are those which do not meet all the requirements ${ }^{34}$ permitting a deduction of expenses "for the management, conservation or maintenance of property held for the

23. See note 1 supra.

24. Estate of Pennell, 4 B.T.A. 1039 (1926).

25. W. S. Dickason, 20 B.T.A. 496 (1930) (defense); if the accident was incident to taxpayer's business the costs of defense would be deductible. S.M. 4078, V-1 Cuxs. Bưl. 226 (1926); O.D. 1117, 5 Cum. Bull. 121 (1921).

26. Fred J. Hughes, 1 B.T.A. 944 (1925) (recovering seized liquor).

27. Robert Edward Kleinschmidt, 12 T.C. 921 (1949) (plaintiff). Newspapers, publishers or professional authors can, however, deduct the cost of defense.

28. Lloyd v. Commissioner, 55 F.2d 842 (7th Cir. 1932) (plaintiff).

29. U.S. Treas. Reg. 118, \$39.24(a)-1 (1953) ; I.T. 1804, II-2 CuM. BuLL. 61 (1923); I.T. 2422, VII-2 CuM. Bull. 186 (1928); O.D. 275, 1 CuM. Bull. 159 (1919).

30. U.S. Treas. Reg., 118, §39.24(a)-1 (1953); Henry Sanderson, 23 B.T.A. 304 (1931); Lindsay C. Howard, 16 T.C. 157 (1951), affd, 202 F.2d 28 (9th Cir. 1953); Robert A. Mckinney, 16 T.C. 916 (1951); Thorne Donnelley, 16 T.C. 1196 (1951); Andrew Jergens, 17 T.C. 806 (1951) ; Estate of Smith, 11 CCH TC MEM. DEC. 1167 (1952); S. B. Tressler, $12 \mathrm{CCH}$ TC MEM. DEC. 358 (1953). The services related to affecting the marital status must be separated from the deductible costs of securing taxable alimony, T.D. 5889, 1952-1 Cum. BuLI. 31, and cases cited note 300 infra, or the preservation in a property settlement of specific income producing property, Baer v. Commissioner, 196 F.2d 646 (8th Cir. 1952), and text at note 335 infra.

31. Croker v. Burnet, 62 F.2d 991 (D.C. Cir. 1933); Esther Rentie, 21 B.T.A. 1230 (1931).

32. Eugene E. Hinkle, 47 B.T.A. 670 (1942).

33. Robert S. Seese, 7 T.C. 925 (1946).

34. Not all expenses of property management are deductible, but only those that meet all of the following requirements:

(1) the property must be of a kind which may produce income, see text at note 328 infra; infra;

(2) the income it will produce must be for the taxpayer, see text at note 256

(3) the taxpayer must hold it for the purpose of producing income or minimizing loss, see text at note 255 infra;

(4) the expense must be for maintaining, conserving or managing the property as contrasted with its acquisition or disposition other than a sale, see text at note 85 infra and discussion of Nancy Reynolds Bagley following note 338 infra. For discussion of disposition by sale, see text following note 303 infra. 
production of income." ${ }^{35}$ Drafting a will, ${ }^{36}$ a deed of trust, ${ }^{37}$ a marital settlement agreement, ${ }^{38}$ the documents incident to borrowing money ${ }^{39}$ or renting a house for use as the taxpayer's residence, ${ }^{40}$ or giving advice about making gifts, ${ }^{41}$ or releasing powers of appointment ${ }^{42}$ all involve property management, but are nondeductible. Efforts to conserve the taxpayer's property generally, by defending him as an endorser on a defaulted note, ${ }^{43}$ or securing a reduction in the rate of interest he pays, ${ }^{44}$ or formerly by contesting a gift tax deficiency, ${ }^{45}$ have also been dismissed as personal.

Sometimes expenses are classified "personal" to lend statutory support to the denial of deductions for legal expenses in vaguely colorable situations, such as disbarment proceedings ${ }^{46}$ or reinstatement to practice before the Treasury. ${ }^{47}$

\section{Capital Expenditures}

Legal fees which are chargeable to capital account for improvements or to increase the value of any property or estate are not currently deductible. ${ }^{48}$ While the 1954 Code ${ }^{49}$ continues all the language of the 1939 Code, $^{50}$ it does clarify the section by titling it "Capital Expenditures." There is still no definition of the concept. ${ }^{51}$

35. I.R.C. $\$ 212(2)$.

36. Estate of Pennell, 4 B.T.A. 1039 (1926).

37. Nancy R. Bagley, 8 T.C. 130 (1947) ; R. C. Coffey, 1 T.C. 579 (1943).

38. See note 30 supra. But a contrary result is reached where the control of a corporation is preserved to taxpayer in such a settlement. See Baer v. Commissioner, 196 F.2d 646 (8th Cir. 1952) and text at note 335 infra.

39. Cynthia K. Herbst, 2 CCH TC Mem. Dec. 361 (1943).

40. R. C. Coffey, 1 T.C. 579 (1943).

41. Lykes v. United States, 343 U.S. 118 (1952).

42. Nancy R. Bagley, 8 T.C. 130 (1947); John W. Willmott, 2 T.C. 321 (1943).

43. Donald V. Smith, 6 CCH TC MeM. Dec. 548 (1947).

44. Bernard Volk, Jr., 12 CCH TC MEM. DEC. 184 (1953).

45. U.S. Treas. Reg. 118, $\$ 39.23$ (a) $-15(\mathrm{k})$ (1953) ; Lykes v. United States, 343 U.S. 118 (1952); Frank M. Cobb, 10 T.C. 380 (1948). As indicated above the Internal Revenue Code of $1954, \$ 212$, now permits these fees to be deducted.

46. Louis S. Levy, 1 CCH TC MeM. Dec. 226 (1942). But cf. Morgan S. Kaufman, 12 T.C. 1114 (1949) (decision did not involve fees incurred in the related disbarment). For further discussion of fees paid in defense of disbarment proceedings, see text at note 138 infra.

47. Tinkoff v. Commissioner, 120 F.2d 564 (7th Cir. 1941). Cf. the Commissioner's position in Hymie Schwartz, 22 T.C. No. 91 (1954).

48. I.R.C. $\$ 263$.

49. I.R.C. $\$ 263$.

50. INT. Rev. Code of 1939, §24(a) (2) (3).

51. The American Law Institute gives an excellent definition, reflecting the trend of most of the existing cases. An expenditure is capital "only if . . it is made primarily for the acquisition, development, or improvement . . . of an asset, interest, or income producing status ..." when either the asset acquired or the benefit derived will last beyond the close of the taxable year. It contrasts ac- 
Capital expenditures, while not deducted as current expenses, do reduce income later by way of depreciation if the property has a determinable life and is held to produce income ${ }^{52}$ or in a business. ${ }^{53}$ If the property does not have a determinable life, the capital expenditure is recovered as increased loss or reduced gain upon abandonment or disposition. $^{54}$

Before the Internal Revenue Code of 1954, expenses of organizing corporations, including legal fees, were not deductible until the corporation was liquidated..$^{55}$ When such fees are paid or incurred after the date of its enactment, the 1954 Code allows the taxpayer to elect to treat them as a deferred expense and deduct them over any period of not less than five years. ${ }^{56}$ The congressional committee reports are careful to point out that this election does not apply to expenditures connected with reorganizations of a corporation unless incident to the creation of an additional corporation, nor to the expenses of issuing shares of stock; ${ }^{57}$ the present case law is also continued for partnership organizations..$^{58}$ Of course, if the newly provided election is not made, and if such costs are still identifiable on the books, a corporation may deduct organizational fees as a loss when it is completely liquidated. $^{59}$ But if the liquidation is part of a merger or reorganization, the loss is not then realized. ${ }^{60}$ The loss is realized when the corporate properties are actually distributed in liquidation, not when a plan to liquidate is adopted. ${ }^{61}$ If distributions occur in several years, the corporation should claim the loss not later than the year in which the bulk of the properties have been dispersed.

quisition, development or improvement with preservation or maintenance expenses which, while restoring the original property life, do not increase it beyond the original life expectancy. 1 Federal Income TAx Statute 284, 285, § X166, comments (Feb. 1954 draft).

52. I.R.C. $\$ 167(a)(2)$.

53. I.R.C. $\$ 167(\mathrm{a})(1)$.

54. I.R.C. $\$ \$ 165(\mathrm{a}), 165(\mathrm{c})(1)$ and (2).

55. U.S. Treas. Reg. 118, \$39.24-a(2) (1953) ; Guarantee Bond \& Mortgage Co. v. Commissioner, 44 F.2d 297 (6th Cir. 1930) ; Clarence Whitman \& Sons, Inc., 11 B.T.A. 1192 (1928); F. Tinker \& Sons Co., 1 B.T.A. 799 (1925).

56. I.R.C. $\$ 248$.

57. H.R. Rep. No. 1337, 83d Cong., 2d Sess. A 64 (1954) ; SEN. REp. No. 1635, 83d Cong., 2d Sess. 224 (1954).

58. Abe Wolkowitz, 8 CCH TC MeM. Dec. 754 (1949). 12 (1934).

59. Malta Temple Association, 16 B.T.A. 409 (1929), acq., X111-2 Cuar. Butr.

60. Citizens Trust Co., 20 B.T.A. 392 (1930).

61. City \& Suburban Mortgage Co., 26 B.T.A. 179 (1932). 
The expenses of amending the corporate charter and authorizing, ${ }^{62}$ issuing, ${ }^{63}$ and initially listing ${ }^{64}$ an increase in capital stock are capital and not deductible, either at the time of the stock issue or upon dissolution, ${ }^{65}$ redemption ${ }^{66}$ or exchange. ${ }^{67}$ The expenses of a bond issue, however, are deductible substantially like interest over the period of the loan, ${ }^{68}$ and the costs of redemption are fully deductible.

Although the cost of legal advice in connection with a taxable, complete liquidation has long been held to be fully deductible if paid or accrued before the formal dissolution of a corporation, ${ }^{69}$ the Commissioner only recently acquiesced in these cases, thus removing any doubts ${ }^{70}$ of the availability of the deduction. The services involved must be rendered before, not after, dissolution. ${ }^{71}$ If the cost of liquidation is assumed by another acquiring the liquidated company's assets, the costs merely increase the cost of the assets acquired; ${ }^{72}$ but, if they are billed to and paid by the liquidated company, the deduction is permitted immediately, whether the assets are conveyed to trustees ${ }^{73}$ or to a parent corporation. ${ }^{74}$

62. Holeproof Hosiery Co., 11 B.T.A. 547 (1928); Durham Brothers \& Co., P-H 1932 BTA MEM. DEC. \ 32,205 (1932).

63. Commissions-Corning Glass Works v. Commissioner, 37 F.2d 798 (D.C. Cir. 1929), cert. denied, 281 U.S. 742 (1930); Simmons Co. v. Commissioner, 33 F.2d 75 (1st Cir. 1929), cert. denied, 280 U.S. 588 (1929); legal and other expenseSurety Finance Co. v. Commissioner, 77 F.2d 221 (9th Cir. 1935) ; Commercial Investment Trust Corp., 28 B.T.A. 143 (1933), aff'd per curiam, 74 F.2d 1015 (2d Cir. 1935); William Cluff Co., 7 B.T.A. 662 (1927); Emerson Electric Mfg. Co., 3 B.T.A. 932 (1926).

64. Gulf, Mobile \& Northern R.R., 22 B.T.A. 233 (1931). In contrast, the annual listing fee is deductible currently. Chesapeake Corp. of Virginia, 17 T.C. 668 (1951), acq., 1952-1 CUM. BULL. 1.

65. Liquidating Company, 33 B.T.A. 1173 (1936); James I. Van Keuren, 28 B.T.A. 480 (1933); III-1 Cum. Bull. 293 (1924); I-1 Cum. Burl. 275 (1922).

66. Merchants Distilling Corp. v. Smith, 2 CCH 1944 TAx CT. Rep. I 9359 (S.D. Ind. 1944).

67. Borg \& Beck Co., 24 B.T.A. 995 (1931), acq., XI-1 Cum. Bull. 2 (1932) as to current deduction for local taxes thus incurred.

68. W. P. Brown \& Sons Lumber Co., 26 B.T.A. 1192 (1932) ; Horn \& Hardart Baking Co., 19 B.T.A. 704 (1930).

69. Rite-Way Products, Inc., 12 T.C. 475 (1949), acq., 1949-2 Cum. Bull. 3, zerithdrazen and nonacq., 1952-2 CUM. BuLL. 5, zerithdrazen and acq., 1954-20 INT. REv. Bull. 4; E. C. Laster, 43 B.T.A. 159 (1940), acq., 1941-1 CUM. BulL. 7, zerithdrazen and nonacq., 1952-2 CuM. BuLs. 5, zerithdrazen and acq., 1954-20 INT. Rev. Burt. 4; Pacific Coast Biscuit Co., 32 B.T.A. 39 (1935), nonacq., XIV-1 CuM. Bull. 35 (1935), nonacq., 1937-1 CUM. BULL. 45, withdrazen and acq., 1954-20 INT. Rev. BULL. 4.

70. See Mills Estate v. Commissioner, 206 F.2d 244, 246 (2d Cir. 1953).

71. J. Gilmore Fletcher, 16 T.C. 273 (1951).

72. Cf. Pidgeon-Thomas Iron Co., 27 B.T.A. 642 (1933).

73. United States v. Arcade Co., 203 F.2d 230 (6th Cir. 1953), affirming 97 F. Supp. 942 (M.D. Tenn. 1951).

74. Commissioner v. Wayne Coal Mining Co., 209 F.2d 152 (3d Cir. 1954), affirming 12 CCH TC MEM. DEC. 345 (1953). 
The Tax Court has followed a similar rule, permitting the deduction of costs of a partial liquidation. ${ }^{75}$ However, the Court of Appeals for the Second Circuit has denied any deduction for such costs if recapitalization is also involved. ${ }^{76}$ Possibly the denial can be justified as analogous to the rules denying a deduction for the demolition of a building on purchased property to make way for a new one. ${ }^{77}$

Expenses of consummated tax-free reorganizations are not deductible, whether effected by way of recapitalization, ${ }^{78}$ consolidation, ${ }^{79}$ merger ${ }^{80}$ or Section 77-B of the Bankruptcy Act. ${ }^{81}$ When the possibility of incorporation or reorganization has been explored and abandoned the costs incurred are deductible as a loss. ${ }^{82}$

Fees paid for advice or in litigation to establish an exclusive right to a trade name, ${ }^{83}$ or in changing zoning ${ }^{34}$ are capital, and, as the benefit is of indefinite duration, they are not deductible or amortizable. No deduction is allowed for legal fees for services in the acquisition or recovery of property ${ }^{85}$ even when the main purpose of the services is management of property to obtain income. ${ }^{86}$

75. Tobacco Products Export Corp., 18 T.C. 1100 (1952); Mills Estate, 17 T.C. 910 (1951), reJ'd, 206 F.2d 244 (2d Cir. 1953).

76. Mills Estate v. Commissioner, 206 F.2d 244 (2d Cir. 1953). In reaching its decision, although basing its holding on the recapitalization aspect, the court appeared to be influenced by the nonacquiescences in the "complete" liquidation cases, which were withdrawn after its decision. See note 69 supra. Therefore, the vitality of the circuit court's opinion may be impaired. The decision is criticized in $102 \mathrm{U}$. of PA. L. Rev. 554 (1954) and 6 Stanford L. Rev. 368 (1954).

77. U.S. Treas. Reg. 118, \$39.23(e)-2 (1953) ; Anahma Realty Corp. v. Commissioner of Int. Rev., 42 F.2d 128 (2d Cir. 1930), cert. denied, 282 U.S. 854 (1930).

78. Skenandoa Rayon Corp. v. Commissioner, 122 F.2d 268 (2d Cir. 1941), cert. denied, 314 U.S. 696 (1941).

79. Beneficial Industrial Loan Corp. v. Handy, 92 F.2d 74 (3d Cir. 1937).

80. Motion Picture Capital Corp. v. Commissioner, 80 F.2d 872 (2d Cir. 1936).

81. Bush Terminal Buildings Co., 7 T.C. 793 (1946); International Building Co. v. United States, 97 F. Supp. 595 (E.D. Mo. 1951).

82. Francis A. Parker, 6 T.C. 974 (1946) (plan to incorporate partnership abandoned); Sibley, Lindsay and Curr Co., 15 T.C. 106 (1950) (reorganization plans abandoned).

83. Food Fair of Virginia, Inc., 14 T.C. 1089 (1950) ; Mark W. Allen \& Co., $1 \mathrm{CCH}$ TC MeM. Dec. 887 (1943).

84. Arthur T. Galt, 19 T.C. 892 (1953). However, if the expense is incurred in an attempt to prevent a change of zoning which would decrease the value of business or income producing property, the fee should be deductible. It does not constitute a capital expense because it does not improve the property in relation to its condition before an application was made to change it. Cf. Memphis Memorial Park, 28 B.T.A. 1037 (1933).

85. Acquisition of stock: Ernest Smith, 5 CCH TC Men. Dec. 7 (1946); Jean Laing Carter, 17 T.C. 994 (1951) (in settlement of patent infringement claim); Raymond K. Dykema, 12 CCH TC MEN. Dec. 462 (1953) (dividend paying in exchange for non-dividend paying). Acquisition of other property: leases-Arthur T. Galt, 19 T.C. 892 (1953); possession from lessee-Johnson v. Commissioner, 162 F.2d 844 (5th Cir. 1947) ; Mississippi Valley Trust Co. v. United States, 61 F. Supp. 451 (E.D. Mo. 1945) ; patents-Hazeltine Corp. v. Commissioner, 89 F.2d 513 (3d Cir. 1937). Recovery of property: Thomas A. Kane, 6 CCH TC MEM. DEc. 222 (1947) (stock given under duress); Hendrick Ranch Royalties, 1 CCH TC MEN. DEc. 794 (1943) (corporate property illegally commingled by corporate officers).

86. Raymond K. Dykema, 12 CCH TC MEM. DEC. 462 (1953). 


\section{TAx Exempt Items}

Legal fees for the recovery of amounts excluded from gross income are not deductible. ${ }^{87}$ The sections of the Code which make the exclusions give a brief catalog of the recoveries, fees for which will be nondeductible: life insurance proceeds payable by reason of death, ${ }^{88} \mathrm{em}-$ ployee's death benefits up to $\$ 5,000,{ }^{89}$ gifts and inheritances, ${ }^{90}$ tax exempt interest, ${ }^{91}$ compensation for injuries or sickness ${ }^{92}$ or received under accident and health plans, ${ }^{93}$ the rental value of parsonages, ${ }^{94}$ discharge of business indebtedness, ${ }^{95}$ improvements on property at the termination of a lease, ${ }^{96}$ armed forces mustering-out payments, ${ }^{97}$ scholarships, fellowships, ${ }^{98}$ and non-shareholder contributions to a corporation. ${ }^{99}$

The statutory bar to deduction in Section 265 is not broad enough to disallow the deduction of fees incurred in collecting punitive damages or treble damages under the antitrust laws. These items are a taxfree windfall, ${ }^{100}$ and not "income" wholly exempt from tax. ${ }^{101}$

87. I.R.C. $\$ 265$, formerly INT. Rev. CoDE of 1939, $\$ 24$ (a) (5), 23 (b).

88. I.R.C. $\S 101$ (a); National Engraving Co., 3 T.C. 178 (1944).

89. I.R.C. $\$ 101(\mathrm{~b})$.

90. I.R.C. § 102 ; U.S. Treas. Reg. 118, \$39.23(a)-15(k) (1953). The rule applies whether the litigation is to oust another beneficiary, C. C. McClees, 4 CCH TC MEM. DEC. 39 (1945), or to obtain a share, Marion A. Burtbeck, 15 T.C. 642 (1950) ; B. M. Spears, 6 CCH TC MEM. DEC. 303 (1947) ; Lindley v. Commissioner, 63 F.2d 807 (2d Cir. 1933) ; Bula E. Croker, 27 B.T.A. 588 (1933). Note that the fee is deductible if it is only to increase the taxpayer's share in income. Stella Elkins Tyler, 6 T.C. 135 (1946); William J. Garland, 2 CCH TC MEM. DEC. 419 (1943).

91. I.R.C. \$103. Cynthia K. Herbst, 2 CCH TC MEM. DEc. 361, 362 (1943). Note that $\$ 265$ does not disallow the deduction of any business expenses (other than interest) allocable to tax exempt interest. This would permit the deduction of the cost of opinions of counsel and investment advisors as to municipal bonds.

92. I.R.C. \$104. Cf. Bercaw v. Commissioner, 165 F.2d 521 (4th Cir. 1948).

93. I.R.C. $\$ 105$.

94. I.R.C. \$107, which was extended to include a monetary rental allowance paid in place of supplying the parsonage itself.

95. I.R.C. $\$ 108$.

96. I.R.C. $\$ 109$.

97. I.R.C. $\S 113$.

98. I.R.C. $\$ 117$.

99. I.R.C. § 118 .

100. Cf. Glenshaw Glass Co., 18 T.C. 860 (1952), aff'd, 211 F.2d 928 (3d Cir. 1954), nonacq., 1953-1 Cun. Bulz. 7; William Goldman Theatres, Inc., 19 T.C. 637 (1953), nonacq., 1953-2 Cum. BuLl. 8, aff'd, 211 F.2d 928 (3d Cir. 1954); Highland Farms Corp., 42 B.T.A. 1314 (1940), acq., 1941-1 Cum. Bull. 5, and nonacq., 1941-1 CuM. Bull. 16.

101. Section 265 only disallows an expense "allocable to... income... wholly exempt from the taxes imposed by this sub-title." (Italics added.) Nor is the problem covered by Pennroad Corp., 21 T.C. No 122 (March 31, 1954) which involved litigation to recoup losses. 


\section{Fees Patd for Another}

An attorney's fee, which might be a deductible item to Jones for whom the work was done, is not deductible by Smith if Smith pays it unless the payment of the sum directly from Smith to Jones would have been deductible by Smith. ${ }^{102}$ If this principle is overlooked, deductions may be lost between husband and former wife, ${ }^{103}$ partner and partnership, ${ }^{104}$ shareholder and corporation, ${ }^{105}$ father and minor son, ${ }^{106}$ executor and estate. ${ }^{107}$ The rule does not apply to. a transferee when he contests the tax liability of the transferor, since the transferee has a personal obligation for the tax payment. ${ }^{108}$ While both trust and beneficiary are separate taxpayers, as a practical matter fees paid by and deductible to the trust now reduce the beneficiaries' taxable income. ${ }^{\mathbf{1 0 9}}$

The 1954 Code has remedied several inequitable results that have arisen under this rule. First, in a Clifford-trust situation, the income of the trust was taxed to the grantor but he was denied the deduction of its expenses on the ground that the trust was a separate entity; ${ }^{110}$ the new law permits such deductions. ${ }^{111}$ Second, under prior law the remainderman was not allowed to deduct the trustee's terminal commission because it was not the remainderman's obligation $;^{112}$ the new law permits remaindermen to take all deductions of a trust which, in its last year, were in excess of its income. ${ }^{113}$ Third, the Treasury had taken the position that when deductible items were charged to trust corpus the life tenant could receive no benefit. ${ }^{114}$ This meant that the tax benefit was completely lost unless the trust itself realized capital gains large enough to offset the deduction, yet small enough not to warrant the use of the alternative tax computation limiting the tax to

102. Cf. Adam, Meldrum \& Anderson Co., 19 T.C. 1130 (1953); Note, 66 HARV. L. Rev. 1508 (1953).

103. Andrew Jergens, 17 T.C. 806 (1951) ; Herbert Marshall, 5 T.C. 1032 (1945). Probably deductible alimony payment to the former wives could have been arranged since they could have deducted the expenses of contesting their own income tax deficiencies.

104. B. W. Sturdivant, 15 T.C. 880 (1950).

105. John J. White, P-H 1942 BTA TC MEM. Dec. $\llbracket 42,288$ (1948).

106. Bercaw v. Commissioner of Int. Rev., 165 F.2d 521 (4th Cir. 1948).

107. Wayne Henderson, 11 CCH TC MEM. Dec. 419 (1952); cf. Dorothy E. Law, 12 CCH TC MEM. DEC. 1440 (1953) (committee and incompetent).

108. Philip D. Armour, 6 T.C. 359 (1946).

109. Mary deF. Harrison Geary, 9 T.C. 8 (1947) (beneficiary); Amy D. McHenry Trust, 6 CCH TC MeM. DEC. 1027 (1947) (beneficiaries and guardians ad litem).

110. Wade E. Moore, 7 T.C. 1250 (1946).

111. I.R.C. $\$ 671$.

112. Anstes V. Agnew, 16 T.C. 1466 (1951).

113. I.R.C. $\$ 642(\mathrm{~h})$.

114. I.T. 3830, 1946-2 CuM. Bulx. 47. 
twenty-five per cent. The new law assures the trust beneficiaries that the benefit of a deductible item charged to and paid from corpus will not be lost. ${ }^{115}$

\section{Public Policy}

A long imposed restriction on the deductibility of business expenses is the public policy doctrine: ${ }^{116}$ disbursements which "frustrate sharply defined national or state policies proscribing particular types of conduct" are disallowed. ${ }^{117}$ Although lacking specific Code recognition, ${ }^{118}$ the doctrine as originally conceived sought statutory support in the rationale that expenses resulting from unlawful or undesirable conduct cannot be considered "ordinary and necessary" to a business. ${ }^{119}$ This statutory prop was removed in 1943 when the Supreme Court in Commissioner $v$. Heininger ${ }^{120}$ stated that the words were to be given their "commonly accepted meaning" in determining whether the expenditure was "normal" to the taxpayer's business in "the circumstances under which [the taxpayer] incurred" them. ${ }^{121}$

In discarding the premise that nothing against public policy was "ordinary and necessary," the Court in Heininger set new standards narrowing the bounds of the doctrine; nine years later the Court in Lilly $v$. Commissioner ${ }^{122}$ added even sharper limits. Therefore, in order to determine the present scope of the public policy restriction, we must first establish what these two decisions did, and then re-examine the previous rulings to see how they have been impaired by,

115. I.R.C. $\S \S 652,662$.

116. This restriction was recognized as early as 1926, in Columbus Bread Co., 4 B.T.A. 1126. The first case dealing with attorneys' fees was apparently Burroughs Bldg. Material Co. v. Commissioner of Int. Rev., 47 F.2d 178 (2d Cir. 1931). While the restriction exists, its justification, if any, requires an open admission that "taxable income" as defined in the Code is not meant to measure an actual economic profit or loss, but may be warped to add income tax sanctions to disapproved conduct. But who must disapprove? Legislators, judges, or administrators? The question is still not answered. Outstanding jurists have not hesitated to add the penalties of an income tax deduction disallowance. Holmes, J., in Clarke v. Haberle Crystal Springs Brewing Co., 280 U.S. 384 (1930), and Learned Hand, J., in Jerry Rossman Corp. v. Commissioner of Int. Rev., 175 F.2d 711, 713 (2d Cir. 1949). At the same time the courts have not seen fit to grant unlegislated income tax benefits for conduct they approved. Cf. Deputy v. duPont, 308 U.S. 488 (1940); Griswold, Gross Income and Deductions, 18 TENN. L. Rev. 539 (1945) ; Griswold, An Argument Against the Doctrine that Deductions Should Be Narrowly Construed as a Matter of Legislative Grace, 56 HaRv. L. Rev. 1142 (1943).

117. Commissioner of Int. Rev. v. Heininger, 320 U.S. 467, 473 (1943).

118. See Lilly v. Commissioner of Int. Rev., 343 U.S. 90, 94 (1952).

119. See Note, 54 Harv. L. Rev. 852, 853 (1941).

120. 320 U.S. 467 (1943).

121. Id. at 471,472 .

122. 343 U.S. 90 (1952). 
and the succeeding ones to see whether they have properly applied, the Heininger and Lilly reasoning.

The expenses in Heininger were attorneys' fees incurred in the unsuccessful attempt to set aside a postal fraud order which, if sustained, threatened to end the taxpayer's business. In holding these fees deductible, the Court applied a two-part test: first, was the expense "ordinary and necessary" in a realistic sense to the taxpayer's business; second, did the expenditure offend sharply defined national or state public policy? Since both questions must be answered in the taxpayer's favor to permit a deduction, the ultimate decision can rest on public policy grounds without reference to any specific section of the Code. The factors the Court considered in answering the latter question were (1) whether the purpose of the statute under which the charges against the taxpayer were brought was to impose "personal punishment" or was designed only to protect the public, and (2) whether the defense against the charge was in good faith.

Although not concerned with attorney fees, the Lilly case followed the bi-partite Heininger test and added the requirement that "the policies frustrated must be national or state policies evidenced by some governmental declaration. . . ." 123 It appears that the Court meant legislative and not judicial or administrative pronouncements of public policy. ${ }^{124}$

While the scope of the doctrine is difficult to delineate precisely, the cases may be conveniently classified into four groups: (1) expenses of defending against charges of criminal business activities; (2) expenses of defending against charges of violations of regulatory statutes; (3) expenses of defending against claims of colorable tortious business activities; (4) expenses of legal but ethically questionable business activities.

\section{Expenses of Defending Against Charges of Criminal Business Activities}

Formerly all expenses of a business, criminal per se, were disallowed except the cost of goods sold. ${ }^{125}$ Recently, however, deductions have been allowed for the "legitimate expenses . . . [of] ille-

123. $I d$. at 97 (italics added).

124. "We voice no approval of the business ethics or public policy involved in the payments now before us. We recognize the province of legislatures to translate progressive standards of professional conduct into law. . ." Id. at 97 (italics added). See Schwartz, Business Expenses Contrary to Public Policy: An Evaluation of the Lilly Case, 8 TAX L. Rev. 241, 248 (1953).

125. Andrew Kjar, P-H 1941 BTA MEM. Dec. $\llbracket 41,446$ (1941) (bootlegging). 
gitimate business" if the expenses themselves directly produce income, ${ }^{126}$ but attorneys' fees paid "to perpetuate or to assure the continuance of an illegal business" are nondeductible. ${ }^{127}$ Where there has been a criminal conviction, ${ }^{128}$ even though an appeal is pending, ${ }^{129}$ or a compromise of criminal charges where violation is admitted, ${ }^{130}$ the attorneys' fees incurred in the defense have been treated no differently than fines or penalties levied as punishment, ${ }^{131}$ and held nondeductible. Although one can see the force of the argument disallowing fines-if deductible this would serve to mitigate the prescribed punishment ${ }^{132}$-it is difficult to conceive of a public policy aimed at deterring persons from making a good-faith defense against criminal prosecutions. ${ }^{133}$

After Heininger, fees incurred in unsuccessful defenses would continue to be nondeductible in cases where "personal punishment" was sought under criminal statutes. When "personal punishment" is given its ordinary meaning, i.e., punishment against the person of the offender and not his pocketbook, ${ }^{13 s}$ then a different result may well obtain where only a fine is, or could have been, sought as punishment. ${ }^{135}$ Shortly after Heininger, the Treasury issued a G. C. M. ${ }^{136}$ allowing a corpora-

126. Cohen v. Commissioner of Int. Rev., 176 F.2d 394, 400 (10th Cir. 1949) (bookies' salaries).

127. Anthony C. Stralla, 9 T.C. 801, 821 (1947) (gambling ship). The Stralla case has been criticized on the ground that the Sixth Amendment establishes a paramount public policy that all criminals shall enjoy the right to have the assistance of counsel for their defense. Krassner, Can a Deduction for Legal Fees Be Against Public Policy?, 26 Taxes 447, 448 (1948).

128. E.g., Burroughs Bldg. Material Co. v. Commissioner of Int. Rev., 47 F.2d 178 (2d Cir. 1931).

129. Joseph Cohen, 2 CCH TC MEM. Dec. 602 (1943).

130. Helvering v. Superior Wines \& Liquors, Inc., 134 F.2d 373 (8th Cir. 1943); cf. Commissioner of Int. Rev. v. Longhorn Portland Cement Co., 148 F.2d 276 (5th Cir. 1945) (penalties only imposed under civil antitrust sections were at issue, since the Commissioner did not appeal the Tax Court's allowance of a deduction for the attorney's fees, 3 T.C. 310 (1944)). But cf. Greene Motor Company, 5 T.C. 314 (1945). The majority of the Tax Court in Greene Motor felt that Heininger is inconsistent with Superior Wines, id. at 321-22, while two dissenting judges thought that Heininger approved it, id. at 323 n.2.

131. See Note, 54 Harv. L. Rev. 852, 853, 855-56 (1941). But cf. Jerry Rossman Corp. v. Commissioner of Int. Rev., 175 F.2d 711 (2d Cir. 1949).

132. Compare view expressed in Commissioner of Int. Rev. y. Longhorn Portland Cement Co., 148 F.2d 276, 277 (5th Cir. 1945), with Lurie, Deductibility of "Illegal" Experses, 11 Ann. Inst. on Fed. Taxation, 1189, 1190-91 (1953).

133. But cf. Judge Learned Hand's argument for denial of attorneys' fees in Jerry Rossman Corp. v. Commissioner of Int. Rev., 175 F.2d 711, 713 (2d Cir. 1949), which overlooks the Heininger requirement of a good-faith defense. See Note, 51 CoL. L. REv. 752, 757 (1951).

134. Cf. Greene Motor Co., 5 T.C. 310, 318 (1945).

135. E.g., PA. Stat. ANN. tit. 681, \$21 (Purdon 1954) (anthracite strip mining without a permit is a misdemeanor subject only to maximum fine of $\$ 5000$ ); MAss. ANN. LAws c. 143, \&23 (Supp. 1953) (obstructing stairways in buildings subject only to fine up to $\$ 500$ ).

136. G.C.M. 24377, 1944 Cum. Bull. 93. This G.C.M. came on the heels of Ionghorn Portland Cement Co., 3 T.C. 310 (1944), acq., 1944 Cum. Bull. 18, allowing the deduction of attorneys' fees incurred in a compromise of a suit for 
tion to deduct its legal expenses in defending a suit brought against it under the Sherman Act ${ }^{137}$ in which it was found guilty. Although the ruling does not seem to have been compelled under strict Heininger reasoning, the Treasury apparently did not choose to limit the deduction of attorneys' fees to antitrust cases where only civil remedies were sought.

In determining the status of fees incurred in an unsuccessful defense against disbarment proceedings, a pre-Heininger Tax Court decision held that since disbarment is "for the present purposes . . . affected by the same considerations" as a criminal prosecution the fees are nondeductible. ${ }^{138}$ This decision is now questionable, as disbarment is not legislative (Lilly) and the precise policy of this action is to protect the public and not to impose personal punishment (Heininger).

Where the defense against criminal charges is successful, ${ }^{139}$ or the criminal charges are compromised and a violation is not admitted, ${ }^{\mathbf{1 4 0}}$ the fees are deductible. In a very recent decision, the Tax Court permitted the deductions of fees of the attorneys whose services on the case terminated before a tax fraud indictment was returned, even though the taxpayer was subsequently convicted. ${ }^{141}$ Of course the activities must also meet the requirement of being proximately related to the taxpayer's business. ${ }^{142}$

\section{Expenses of Defending Against Charges of Violation of Regulatory Statutes}

Where the taxpayer has been held to have violated a regulatory statute-i.e., one which provides only a money penalty and/or injunctive relief-the attorneys' fees incurred in a good-faith defense of the charges should be deductible. Coming within this factual situation are the cases, like Heininger, dealing with the fees of an unsuccessful de-

civil antitrust penalties. The ruling was based solely on the grounds that a good-faith defense against antitrust charges is as necessary to a business as the attack on the mail fraud order was in Heininger; it did not consider the second part of the Heininger test- whether allowance of the expense would frustrate public policy. Guilt under the Sherman Act falls squarely within the Lilly (legislative policy) and Heininger ("personal punishment") conception of nondeductible activity. The Sherman Act does provide for personal punishment, although incapable of being executed upon a corporation. See generally, Smith, Deductions by Corporations of Expense of Litigation in their Defense of Alleged Anti-Trust Violations, 8 ANs. INST. ON FEd. TAXATION 646 (1950).

137. 26 Stat. 209 (1890), as amended, 50 Stat. 693 (1937), 15 U.S.C. \$\$ 1, 2 (Cum. Supp. 1953).

138. Louis S. Levy, 1 CCH TC Mem. Dec. 226 (1942). See also Tinkoff v. Commissioner of Int. Rev., 120 F.2d 564 (7th Cir. 1941) ; G.C.M. 23438, 1942-2 Cum. Bull. 188.

139. E.g., Commissioner of Int. Rev. v. People's-Pittsburgh Trust Co., 60 F.2d 187 (3d Cir. 1932).

140. Greene Motor Company, 5 T.C. 314 (1945), acq., 1945 Cux. Bulz. 3. See note 130 supra.

141. Hymie Schwartz, 22 T.C. No. 91 (1954).

142. See 4 Mertens, Law of Federal Income Taxation 385-86 and n.10. 
fense against statutory charges where only injunctive relief is sought. ${ }^{143}$ As the Treasury permits the deduction of fees, at least for corporate defendants, where criminal guilt under the Sherman Act ${ }^{144}$ is established, to be consistent the Commissioner should not question the deductibility of fees when only injunctive remedies are sought and imposed for antitrust violations. ${ }^{145}$

Where regulatory statutes provide for a monetary exaction from a taxpayer in the nature of a penalty, many cases have denied deductibility to the penalties ${ }^{146}$ but, again reasoning a fortiori from the Treasury's position on fees of criminal antitrust violations, the fees incurred in defense of the penalties should be deductible. In Longhorn Portland Cement Co., ${ }^{147}$ the Tax Court allowed the fees incurred in a compromise of a non-criminal antitrust prosecution where, although the defendant did not admit to a violation, large penalties were assessed. The Treasury has also allowed the deduction of fees connected with an unsuccessful defense of civil sections of OPA regulations where treble damages are provided. ${ }^{148}$ Heininger, although not concerned with a statute providing monetary penalties, is helpful on this issue in the respect that it warns that an administrative finding of guilt in quasicriminal cases is not to be a "rigid criterion" in determining deductibility of attorneys' fees. ${ }^{149}$ If, therefore, an exaction is held to be a penalty but not one which, by its deduction, would frustrate public policy and is consequently deductible itself, ${ }^{150}$ a fortiori legal fees associated with the litigation should be deductible. Of course, if the exaction is not considered a penalty but restitutionary in nature and therefore deductible, ${ }^{151}$ the legal fees incurred in the defense should receive similar treatment.

\section{Expenses in Defense of Colorable Tortious Activities}

It had long been held that costs of defending against suits by private parties for fraud, breach of corporate fiduciary duty, malpractice,

143. E.g., PA. Stat. ANN. tit. 63, $\$ 440$ (Purdon Supp. 1953) (revocation of real estate operator's license for misleading or untruthful advertising) ; MASs. ANN. LAws c. $175, \S 193 \mathrm{~A}$ (1948) (enjoining insurance companies from issuing policies).

144. See text at note 136 supra.

145. This means that National Outdoor Advertising Bureau, Inc. v. Helvering, 89 F.2d 878 (2d Cir. 1937) should be considered overruled.

146. See note 131 supra. $1945)$.

147. 3 T.C. 310 (1944), other issues appealed and rev'd, 148 F.2d 276 (5th Cir.

148. G.C.M. 24810 1946-1 CuM. BuLx. 55.

149. Commissioner v. Heininger, 320 U.S. 467,475 (1943).

150. Jerry Rossman Corp. v. Commissioner of Int. Rev., 175 F.2d 711 (2d Cir. 1949) (question three).

151. Id. (question one). 
negligence and patent infringements are deductible even though unsuccessful. ${ }^{162}$ Where an executor or trustee has settled charges of mismanagement of estate property, the deductibility of legal fees incurred in the controversy depends on whether the taxpayer can be considered engaged in business. ${ }^{153}$ If not so engaged, deductions have not been permitted as a non-business expense ${ }^{154}$ on the grounds that this would subsidize delinquent trustees. As deductions have been permitted where the taxpayer has been convicted of criminal activities and where regulatory statutes have been violated, the nondeductibility of these fees arising out of tort charges seems unrealistic.

\section{Expenses of Legal But Ethically Questionable Business Activities}

Contrasted with the preceding categories, here are involved payments to attorneys for services not connected with actual or possible litigation, services of a nature that could also be performed by nonlawyers. Therefore, the decisions dealing with payments to nonlawyers are precedents for fees paid to attorneys for similar services.

Although no statute has been violated, courts have denied deductibility to payments for influence and favorable consideration in securing contracts for the taxpayer. ${ }^{155}$ This policy does not extend to a lawyer's legitimate efforts to get contracts for his clients, even though he is well acquainted with the proper contracting officers. ${ }^{156}$

The status of fees for lobbying activities not violative of any statute presents an interesting question. The regulations have consistently denied deductibility for such payments ${ }^{157}$ and the Supreme Court in Textile Mills Securities Corp. v. Commissioner of Internal Revenue ${ }^{168}$ held that the regulations were determinative of the question in disallowing payments made to publicists and lawyers where the taxpayer was attempting to secure favorable legislation not for its own business but for the interests of others on a contingent fee basis. Previous to Textile Mills, in cases dealing with lobbying expenses designed to benefit the taxpayer's own business, and not incurred on a contingent fee basis, the Board of Tax Appeals took the position that where "the

152. For collection of cases, see Note, 54 HARv. L. REv. 852, 856 (1941).

153. Commissioner of Int. Rev. v. Macy, 2d Cir., Sept. 21, 1954. For more complete discussion of this problem, see text at note 217 infra.

154. Commissioner of Int. Rev. v. Heide, 165 F.2d 699 (2d Cir. 1948) ; Commissioner of Int. Rev. v. Josephs, 168 F.2d 233 (8th Cir. 1948).

155. For collection of cases, see Note, 51 Cot. L. Rev. 752, 759-60 (1951).

156. Aetna-Standard Engineering Co., 15 T.C. 284 (1950); Alexandria Gravel Co. v. Commissioner of Int. Rev., 95 F.2d 615 (5th Cir. 1938).

157. U.S. Treas. Reg. 118, $\$ 39.23(\mathrm{~g})-1$ (a) (1953). For history of the regulations, see Textile Mills Securities Corp. v. Commissioner of Int. Rev., 314 U.S. 326 (1941).

158. 314 U.S. 326 (1941). 
means or methods employed are legitimate" 159 and not "something sinister," 160 the expenses were deductible. The Ninth Circuit in Sunset Scavenger Co.v. Commissioner of Internal Revenue ${ }^{181}$ overruled one of these decisions, relying wholly on the effect of the regulations. At first glance, this case would appear to be just a forerunner to Textile Mills, but the Court there did not even mention Sunset Scavenger, strange indeed since the reasoning was so parallel. It is reasonable to assume that, since the lobbying expenses in Sunset Scavenger and Textile Mills were radically different, this omission was not unintentional and, therefore, the Court did not intend to preclude the deductibility of all types of lobbying expenses. Support for this opinion is found in the Lilly case where, in discussing Textile Mills, the Court pointed out that that decision disallowed only "some types" of lobbying expenses. ${ }^{162}$

Applying the Heininger and Lilly tests, it is rather doubtful that the "influence" cases would be changed; it is difficult to imagine any court saying that it is ordinary and necessary for a business to secure contracts by buying influence, and part two of the Heininger test-the frustration question-may never be reached. This is not so with lobbying expenses; it is just as normal to attempt to save a business threatened with extinction or harm by adverse legislation as by a mail fraud order. On the public policy question, disallowance of lobbying expenses perhaps meets the Lilly test if the regulations be considered a "governmental declaration" of a legislative character by reenactment, but, as we are not considering here activities prohibited by statutes, the "personal punishment" factor of Heininger cannot be present. Therefore, it cannot be said that these two cases dictate any one result and it would appear that deductibility of lobbying expenses depends on the willingness of courts to distinguish the Textile Mills case.

\section{Defense of Title}

"Expenditures incurred in defending or perfecting title to property . . . constitute a part of the cost of the property and are not deductible expenses." 163 This, or almost identical language, has appeared in the regulations since 1919. ${ }^{164}$ From nearly the beginning

159. Los Angeles \& Salt Lake R.R., 18 B.T.A. 168, 179 (1929).

160. Sunset Scavenger Co., 31 B.T.A. 758, 763 (1934). Also, Lucas v. Wofford, 49 F.2d 1027 (5th Cir. 1931), affirming 15 B.T.A. 1225 (1929).

161. 84 F.2d 453 (9th Cir. 1936).

162. Lilly v. Commissioner, 343 U.S. 90, 95 (1952). Cf. Note, 67 HaRv. L. Rev. 1408,1414 (1954).

163. U.S. Treas. Reg. 118, \$39.23 (a)-15(k) (1953).

164. U.S. Treas. Reg. 45, Art. 293 (1920 ed. 1921); U.S. Treas. Reg. 62, Art. 293 (1922) ; U.S. Treas. Reg. 65, Art. 292 (1924) (Rev. Act 1924); U.S. 
of the income tax, the "defense of title" doctrine has limited the deduction for business expenses.

In $1920^{\mathbf{1 6 5}}$ and 1921 , $^{166}$ Bureau rulings refused to allow the deduction of attorneys' fees for defending or quieting title either as a loss or as an expense. The doctrine was extended in 1922 to include the costs of defending against any threat to the value of the property, even though title was not directly in issue. ${ }^{167}$ In the next year the costs of recovering property were placed in the same nondeductible category. ${ }^{168}$

The Board of Tax Appeals went along with broadening of the doctrine by disallowing the expense of a defense against a Government suit to prevent the owner from taking oil from its wells. ${ }^{169}$ It was then an easy judicial jump to disallow practically all the expenses of litigation involving oil royalties. ${ }^{170}$

In disallowing expenses of litigation involving patent royalties, the Treasury met a temporary hurdle in its own regulations ${ }^{\mathbf{1 7 1}}$ which stated specifically (and still do ${ }^{172}$ ) what entered into the "cost" of a patent. In 1920 the Committee on Appeals and Review of the Bureau of Internal Revenue reasoned that attorney's fees for defending a patent after its issue were fully deductible because they did not prolong its life; they were not an "improvement or betterment"; and they were not recoverable through depreciation based on its "cost" as defined in the regulations. ${ }^{173}$ By 1947 this early ruling had been forgotten, though not revoked or modified, and is not even mentioned in a case holding

Treas. Reg. 69, Art. 292 (1926) (Rev. Act 1926) ; U.S. Treas. Reg. 74, Art. 282 (1929) (Rev. Act 1928) ; U.S. Treas. Reg. 77, Art. 282 (1933) (Rev. Act 1932); U.S. Treas. Reg. 94, Art. 24-2 (1936) (Rev. Act 1936) ; U.S. Treas. Reg. 101, Art. 24-2 (1939) (Rev. Act 1938); U.S. Treas. Reg. 103, \$19.24-2 (1940); U.S. Treas. Reg. 111, § 29.24-2 (1943).

165. A.R.R. 284, 3 Cum. Bull. 208 (1920).

166. A.R.R. 701, 5 CuM. Bull. 176 (1921).

167. I.T. 1382, I-2 CuM. Bull. 146 (1922).

168. A.R.R. 2318, II-1 CuMr. BuzL. 82 (1923). While this ruling dealt with costs of recovering property in kind from the Alien Property Custodian, an earlier ruling, O.D. 1048, 5 CUM. Bull. 127 (1921), involved the proceeds if the property had been sold. Under Agnes Pyne Coke, 17 T.C. 403 (1951), aff'd, 201 F.2d 742 (5th Cir. 1953), the fee might be deductible in full if the A.P.C. has sold the property.

169. Consolidated Mutual Oil Co., 2 B.T.A. 1067 (1925); cf. North American Oil Consolidated, 12 B.T.A. 68 (1928).

170. Murphy Oil Co. v. Burnet, 55 F.2d 17 (9th Cir. 1932); Blackwell Oil \& Gas Co. v. Commissioner of Int. Rev., 60 F.2d 257 (10th Cir. 1932) ; Moynier v. Welch, 97 F.2d 471 (9th Cir. 1938); Manhattan Land \& Fruit Co., 1 CCH TC MEM. DEC. 217 (1942) ; Porter Royalty Pool, Inc., 7 T.C. 685 (1946), aff'd, 165 F.2d 933 (6th Cir.), cert. denied, 334 U.S. 833 (1948).

171. U.S. Treas. Reg. 33, Art. 174 (1918).

172. U.S. Treas. Reg. 118, $\$ 39.23(1)-7$ (1953).

173. A.R.R. 98, 2 Cum. Bull. 105, 107 (1920). 
that the costs of defending the exclusive right to make, use and sell under a patent are not deductible. ${ }^{174}$

Although in 1928 the Supreme Court was "unable to perceive any real distinction between an expenditure for attorneys' fees made to secure payment of the earnings of the business and a like expenditure to retain such earnings after their receipt," 175 in a royalty case the Tax Court 176 limited the "earnings of business" language to specific earnings rather than including fees for litigation claiming all earnings from a patent or agreement. In an important recent decision, the Third Circuit has at long last heeded the twenty-six year old language of the Supreme Court and bluntly stated that in litigation over patent royalties validity of the patent is normally called into question, but that fact does not make the attorney's fees any less deductible as ordinary business expenses. ${ }^{17 \tau}$

Following the long administrative policy of curtailment of allowable business expense deductions, the Bureau, promptly after the 1942 amendments to the Code, inserted the defense of title limitation in the regulations on these amendments ${ }^{178}$ which allowed a deduction of the expenses of producing income, or of managing, conserving, or maintaining property held for the production of income. The draftsmen of these regulations must have felt its repetition necessary, because, as administratively overexpanded, the defense of title doctrine is nowhere spelled out in the Code and is so contradictory to the specific deduction allowed for "expenses... . for the . . . conservation or maintenance of property." 178

174. Safety Tube Corp., 8 T.C. 757 (1947), aff'd, 168 F.2d 787 (6th Cir. 1948). But cf. Urquhart v. Commissioner of Int. Rev., 215 F.2d 17 (3d Cir. 1954), reversing 20 T.C. 944 (1953), discussed in note 177 infra.

175. Kornhauser v. United States, 276 U.S. 145, 153 (1928).

176. Safety Tube Corp., 8 T.C. 757 (1947).

177. Urquhart v. Commissioner of Int. Rev., 215 F.2d 17 (3d Cir. 1954), reversing 20 T.C. 944 (1953). Note that the Court of Appeals for the Third Circuit overlooks the demurrer in Safety Tube, supra note 174, which removed the issue of "title" and left the litigation a matter of who owned the royalties.

178. U.S. Treas. Reg 103, $\$ 19.23$ (a) -15, added by T.D. 5196, 1942-2 Curs. Burl. 96, 99-100; U.S. Treas. Reg. 111, \$29.23(a)-15(b) (1943) ; U.S. Treas. Reg. $118, \S 39.23(\mathrm{a})-15(\mathrm{~h})(1953)$.

179. InT. Rev. CODE of $1939, \S 23$ (a) (2) ; I.R.C. $\$ 212(2)$. To date the limitation in the non-business regulations, U.S. Treas. Reg. 118, $\$ 39.23(\mathrm{a})-15(\mathrm{k})$ (1953) contains a parenthetical exception which seems to have passed completely without judicial interpfetation. It provides, "Expenditures incurred . . . in recovering property (other than investment property and amounts of income which, if and when recovered, must be included in income) . . constitute a part of the cost of the property and are not deductible expenses." As amounts "which . : must be included in income" are "amounts of income," the only grammatical interpretation is that expenses of recovering "investment property" are not part of its cost but are deductible currently. This is consistent with allowing a receiver to deduct his legal expenses incurred in recovering an overpayment by the company to its attorney, notwithstanding the Commissioner's objection that "title" to the fund was in issue. Missouri-Kansas Pipe Line Co., 3 CCH TC MEM. DEC. 15 (1944). 
The administrative transposition of the defense of title limitation from business to non-business expenses was soon judicially perpetuated. Although a district court pointed to the new section in the Code and justified the deduction of the costs of successfully defending a suit to invalidate the taxpayer' spurchase of corporate stock, ${ }^{180}$ the circuit court $^{181}$ found, in the legislative history ${ }^{182}$ and in the regulations, ${ }^{183}$ that:

"A deduction under this section is subject to all the restrictions and limitations that apply in the case of the deduction : . . of an expense paid or incurred in carrying on any trade or business."

Thus administrative custom circumscribed broad statutory language.

Thereafter the rule was extended not only to fees paid in the defense of actual will contests, ${ }^{184}$ but also to the mere taking of a deposition when there was a suspicion of such a contest. ${ }^{185}$ Here the application of the rule raises a practical problem for which there is no satisfactory answer. Such suits are usually brought against the beneficiary who takes the bulk or residue of an estate, consisting of stocks and bonds, many with an established market value at death which under the Code will become their "basis," 186 and perhaps a variety of assets in an unincorporated business. ${ }^{187}$ It is difficult to believe that the judges who denied the deduction gave much thought to how the taxpayer was to go about breaking up his litigation expenses among the various items of property involved and adding them to their respective costs. Moreover, in the case where the property has an established market value, the addition of such expenses to "cost" merely forces up the basis artificially-since the value on the market in no way is affected-and creates a fictitious "capital loss," which may never be deductible.

180. Lumpkin v. Bowers, 50 F. Supp. 874 (E.D.S.C. 1943).

181. Bowers v. Lumpkin, 140 F.2d 927 (4th Cir.), cert. denied, 322 U.S. 755 (1944).

182. H.R. Rep. No. 2333, 77th Cong., $2 d$ Sess. 75 (1942), 1942-2 CuM. Bult. 372, 430; SEN. Rep. No. 1631, 77th Cong., 2d Sess. 88 (1942), 1942-2 Cum. Bull. 504,571 .

183. U.S. Treas. Reg. 103, $\$ 19.23$ (a) -15, added by T.D. 5196, 1942-2 Cum. BurL. 96, 99-100; U.S. Treas. Reg. 111, §29.23(a)-15(b) (1943) ; U.S. Treas. Reg. 118, $\$ 39.23(\mathrm{a})-15(\mathrm{k})$ (1953).

184. U.S Treas. Reg. 111, \$29.23(a)-15(b) (1943); U.S. Treas. Reg. 118, $\S 39.23(\mathrm{a})-15(\mathrm{k})$ (1953). Irene D. Addison, 7 CCH TC Men. Dec. 644 (1948), aff'd, 177 F.2d 521 (8th Cir. 1949).

185. James C. Coughlin, 3 T.C. 420 (1944).

186. I.R.C. \$1014.

187. See James C. Coughlin, 3 T.C. 420 (1944). 
There have been hopeful suggestions that there are exceptions to the "defense of title" rule. ${ }^{188}$ The three mentioned were the cases in which the "title" defended was (a) to property acquired as income, (b) involved in a mere nuisance suit, or (c) incidental to or involved only as a consequence of other allegations. These exceptions have narrow limits.

The cases involving title to income are limited to the defense or recovery of specific items, ${ }^{189}$ and do not extend to income, such as royalties, for an indefinite period. ${ }^{190}$

The idea that expenses of settling mere nuisance suits are deductible stems from Judge Learned Hand's opinion in Levitt \& Sons, Inc. v. Nunan. ${ }^{191}$ The rule there established is worthy, if a bit narrow, in the settlement experience of most lawyers. Judge Hand would allow the deduction of the costs of a settlement, including attorney's fees, even if a claim to title had been made by the plaintiff, if all three of the following tests were met: (1) the taxpayer is "entirely confident that any suit which . . . [the plaintiff] might bring could not succeed," and (2) the taxpayer makes "the payment in question only for the purpose of avoiding the damage to its credit, its reputation, and its business generally which might result from such a suit," and (3) ". . . any such fear which it may have had, [was] so far justified that a reasonable person in its place would have thought a settlement at that figure less than the damage which would follow from such a suit." 192

In several cases the taxpayer has tried to meet this test. None has succeeded, ${ }^{193}$ including the taxpayer in the Levitt case. ${ }^{194}$ The deduction has been denied where the testimony showed, probably to his embarrassment, that the settlement was made only after counsel had ad-

188. Everett, Deductibility of Legal and Accounting Fees, 6 ANN. INST. FED. TAXATION 616, 628-33 (1948).

189. Kornhauser v. United States, 276 U.S. 145 (1928) (stock received as a fee) ; O'Day Investment Co., 13 B.T.A. 1230 (1928), acq., VIII-1 CUM. Bull. 34 (1929) (defense to accounting in receivership action); Udolpho Wolfe Co., 15 B.T.A. 485, acq., VIII-2 CuM. Bull. 57 (1929) (unsuccessful action to recover excessive compensation paid in prior year) ; Bula E. Croker, 27 B.T.A. 588 (1933) (expense of suing an agent for sale of lands and collection of interest); Pierce Estates, Inc., 3 T.C. 875 (1944), nonacq., 1944 Cum. Buls. 51 (claim to royalties under words used in oil and gas contract).

190. Porter Royalty Pool, Inc., 7 T.C. 685 (1946), aff'd, 165 F.2d 933 (6th Cir.), cert. denied, 334 U.S. 833 (1948); Safety Tube Corp., 8 T.C. 757 (1947), aff'd, 168 F.2d 787 (6th Cir. 1948) See text at note 176 supra.

191. 142 F.2d 795 (2d Cir. 1944).

192. $I d$. at 798.

193. Condenser Service \& Engineering Co., $10 \mathrm{CCH}$ TC MEM. DEC. 911 (1951), aff'd, 200 F.2d 959 (3d Cir. 1953) (over $\$ 478,000$ claim settled for $\$ 97,500$ ) ; E. W' Brown, Jr., 19 T.C. 87 (1952) (settled for less than 1/6th of claim).

194. Levitt \& Sons, Inc., 2 CCH TC MEM. DEc. 127 (1943), rev'd and remanded, 142 F.2d 795 (2d Cir. 1944); 5 T.C. 913 (1945), aff'd, 160 F.2d 209 (2d Cir. 1947). 
vised that the amount paid would be deductible under these requirements. ${ }^{195}$ The Tax Court has held that settling a will contest for less than one-sixth of the increase the contestant demanded could not qualify as settling a nuisance suit. ${ }^{196}$

The most successful counter-measure to a claim that an expense was in defense of title is to show that, while title may have come up, it was purely incidental to the main issue, ${ }^{\mathbf{1 9 7}}$ or to the capacity in which the taxpayer was sued-for example, that he was sued for malfeasance as an officer or director and that therefore title to the stock acquired in breach of duty was only a matter of remedy ${ }^{198}$ - or better still that it was not the taxpayer's title which was in issue. ${ }^{199}$ But the issue of title does not become merely incidental when it is successfully eliminated as an issue on demurrer at the beginning of the litigation which continues bitterly as a suit for accounting for royalties. ${ }^{200}$

As applied in many of these cases, the rule has aroused deserved disrepute. The American Law Institute recommends that it be modified "to permit an expense deduction where nothing is accomplished beyond preservation of an existing title." 201

The defense of title rule is unwarranted because often the expense, though necessary, adds nothing to the value of the property. The Code disallows only ". . . any amount paid out . . . to increase the value of any property or estate." ${ }^{202}$ Only rarely does the Treasury or a court recognize that the cost of litigation is deductible because it has not increased the value of the property involved. ${ }^{203}$

Moreover, the true test should be an increase over value at the time the instant taxpayer obtained the property, not an increase in the

195. Condenser Service \& Engineering Co., Inc., $10 \mathrm{CCH}$ TC MEM. DEc. 911, 915 (1951), aff'd, 200 F.2d 959 (3d Cir. 1953).

196. E. W. Brown, Jr., 19 T.C. 87 (1952).

197. William C. Atwater \& Co., 10 T.C. 218 (1948) (primary problem compensating an employee); Hochschild v. Commissioner of Int. Rev., 161 F.2d 817 (2d Cir. 1947) (primary charge corporate breach of trust) ; Rassenfoss v. Commissioner of Int. Rev., 158 F.2d 764 (7th Cir. 1946) (primary charge partnership accounting); Heller v. Commissioner of Int. Rev., 147 F.2d 376 (9th Cir.), cert. denied, 325 U.S. 868 (1945) (primary claim for cash value of dissenters' shares in merger); General Pencil Co., 3 CCH TC MEM. DEC. 603 (1944) (primary effort to end ex-president's troublemaking).

198. Hochschild v. Commissioner of Int. Rev., 161 F.2d 817 (2d Cir. 1947), reversing 7 T.C. 81 (1946).

199. Cooper Foundation, 13 T.C. 209 (1949).

200. Safety Tube Corp., 8 T.C. 757 (1947), aff'd, 168 F.2d 787 (6th Cir. 1948); but see Urquhart v. Commissioner of Int. Rev., 215 F.2d 17 (3d Cir. 1954).

201. 1 American Law Institute, Federal Income Tax Statute 285, § X166(a), comment (Feb. 1954 Draft).

202. I.R.C. $\$ 263(\mathrm{a})(1)$ (italics added).

203. A.R.R. 98, 2 CuM. BuLt. 105 (1920); Reakirt v. Commissioner of Int. Rev., 29 B.T.A. 1296 (1934), aff'd without opinion, 84 F.2d 996 (6th Cir. 1936); Bliss v. Commissioner of Int. Rev., 57 F.2d 984 (5th Cir. 1932), before being overruled by Jones' Estate v. Commissioner of Int. Rev., 127 F.2d 231 (5th Cir. 1942). 
value over what it would have been had the contest not been made. ${ }^{204}$ In the case of patents, or lands which subsequently prove valuable, the claims may be made many years after the title has been reasonably established and perfected, and are often in the nature of strike suits. It is not impossible to draw the necessary line between "capital" and "expense" items. The line is the same and constantly drawn between physical repairs and capital improvements.

\section{Trade or Business Expenses}

If your fee has not fallen into one or more of the preceding six nondeductible categories, you may well find justification enough for a deduction in the two sections of the 1954 Code and the prior decisions next considered.

\section{Individuals}

The individual carrying on any trade or business can deduct a reasonable amount for legal services actually rendered to the business. ${ }^{205}$ When a connection between the legal services and the business was shown, the Tax Court allowed a deduction for fees for counselling a witness before a congressional hearing ${ }^{206}$ and an author regarding "literary affairs." 207 An employee may deduct the cost of legal advice on his rights under an employment contract. ${ }^{208}$

The cost to an individual of bringing ${ }^{200}$ or defending ${ }^{210}$ a suit for an accounting for partnership income, profits, or property is fully deductible; costs of such an action cannot be capitalized. ${ }^{211}$ A lawyer or doctor may deduct his costs of defending a suit for damages arising from the profession brought by a client or patient. ${ }^{212}$ Similarly, a corporate officer's costs of defending a suit to oust him, ${ }^{213}$ or charging

204. Cf. 1 American Law Institute, Federal Income Tax Statute 285, $\S \mathrm{X166(a)}$, comment (Feb. 1954 draft).

205. I.R.C. $\$ 162(a)(1)$.

206. Waldo Salt, 18 T.C. 182 (1952), acq., 1952-2 Cum. Bunt. 3.

207. Pelham G. Wodehouse, 8 T.C. 637 (1947), acq., 1947-2 Cum. Burl. 5.

208. Arthur N. Blum, 11 T.C. 101 (1948), aff'd, 183 F.2d 281 (3d Cir. 1950), acq., 1949-1 CuM. BuLc. 1.

209. Cf. Orien H. Anderson, 8 CCH TC MEN. DeC. 740 (1949).

210. Kornhauser v. United States, 276 U.S. 145 (1928) ; Rassenfoss v. Commissioner of Int. Rev., 158 F.2d 764 (7th Cir. 1946) ; Andrew Siarto, 6 CCH TC MeM. Dec. 3 (1947), aff'd, Siarto v. Commissioner of Int. Rev., 171 F.2d 293 (6th Cir. 1948); Marsh v. Squire, 1 CCH 1948 TAx CT. Rep. $\int 9142$ (W.D. Wash. 1947). (1953).

211. Suckow Borax Mines Consolidated, Inc., $12 \mathrm{CCH}$ TC MEM. Dec. 786

212. S.M. 4078, V-1 Cun. But.. 226 (1926).

213. E. L. Potter, 20 B.T.A. 252 (1930), nonacq., X-1 Cum. BurL. 90 (1931). 
mismanagement, ${ }^{214}$ breach of fiduciary duties, ${ }^{215}$ or misappropriation of funds ${ }^{216}$ are fully deductible.

If an individual's activities as an executor or trustee are sufficient in scope and duration so that he is considered to be in business in such capacities, in settling mismanagement charges not only his legal expenses but the amount paid in settlement are deductible. ${ }^{217}$ In the very recent case of Commissioner of Internal Revenue $v$. Macy, ${ }^{218}$ the Second Circuit held that a person can be in the business of being an executor or trustee even if his duties concern only one estate or trust. If a trustee cannot so qualify, he does not fare so well. In two circuit court decisions, neither his legal costs nor the settlement payments were allowed on the grounds that this would be subsidizing delinquent fiduciaries. ${ }^{219}$ These decisions seem unrealistic on the public policy grounds ${ }^{220}$ and the Macy case casts additional doubts on their present validity.

\section{Corporations}

Where the corporation has paid the litigation expenses of its officers or directors in suits brought against them, the corporation has been allowed to deduct such expenses, or a part of them, when it has received a benefit or had a legal obligation to pay them. In the benefit cases the Tax Court tends to bear heavily on the taxpayer, allocating only a small proportion of the fee to the corporate benefit. ${ }^{21}$ Where the litigation arose over the terms of a pledge of stock belonging to one of its officers but used to secure corporate borrowing, the corporation was allowed to deduct the full amount of the legal fees. ${ }^{222}$

A provision in the corporate by-laws providing indemnification to directors and officers for expenses in the defense of suits arising out of having been a director or an officer helps to assure a deduction to

214. Dixon Fagerberg, P-H 1942 BTA-TC MEM. Dec. $\llbracket 42,091$ (1942) (unauthorized corporate speculation).

215. William L. Butler, 17 T.C. 675 (1951), acq., 1952-1 Cum. Bull. 1 (wife profited from insider information); Hochschild v. Commissioner of Int. Rev., 161 F.2d 817 (2d Cir. 1947) (officers' shares in profitable corporate purchase).

216. Mrs. A. B. Hurt et al., Executors, 30 B.T.A. 653 (1934), remanded on compromise, 90 F.2d 1010 (5th Cir. 1937).

217. Commissioner of Int. Rev. v. Macy, 215 F.2d 875 (2d Cir. 1954); John Abbott, 38 B.T.A. 1290 (1938).

218. 215 F.2d 875 (2d Cir. 1954).

219. Commissioner of Int. Rev. v. Heide, 165 F.2d 699 (2d Cir. 1948) ; Commissioner of Int. Rev. v. Josephs, 168 F.2d 233 (8th Cir. 1948).

220. See text at note 154 supra.

221. Davis B. Thornton, 4 CCH TC MEM. DEC. 29 (1945) ; Standard Galvanizing Co., 11 CCH TC Mem. DEC. 170 (1952), rev'd, 202 F.2d 736 ' (7th Cir. 1953).

222. Standard Galvanizing Co. v. Commissioner of Int. Rev., 202 F.2d 736 (7th Cir. 1953). 
the corporation. ${ }^{223}$ With such a provision in the by-laws, the Tax Court in the recent Union Investment $C o$. case has allowed the corporation to deduct the expense of successfully defending an officer against a criminal charge of conspiring to influence legislation, a decision that received the Commissioner's acquiescence. ${ }^{224}$ An earlier Treasury ruling took the position that, where the defense has not been successful, expense to defend its officers is not a corporate deduction under the rationale that the payment is the expense of another. ${ }^{225}$ This position does not seem realistic, since such indemnity may well be a fringe benefit necessary to induce officers and directors to serve, deductible in any event to the corporation as reasonable compensation, ${ }^{226}$ and the acquiescence in the Union Investment case seems to indicate a change in result.

Where the title to property is not primarily involved, the corporation may deduct the cost of defending actions brought directly against it, such as for violation of the antitrust laws ${ }^{227}$ or Office of Price Administration ceilings, ${ }^{228}$ for Securities and Exchange Commission investigations and stockholders' suits incidental thereto, ${ }^{229}$ to declare it bankrupt, ${ }^{230}$ to restrain the holding of the annual meeting, ${ }^{231}$ for damages for acquiring assets by fraud at an inadequate price, ${ }^{232}$ or for damages caused by the negligence of its employees. ${ }^{233}$

The legal costs of planning for corporate extinction, ${ }^{234}$ but not contraction, ${ }^{235}$ are deductible in full. An equivalent deduction as a loss ${ }^{238}$ arises when corporate plans of recapitalization, ${ }^{237}$ merger, ${ }^{238}$ or

223. Union Investment Company, 21 T.C. No. 74 (1954); Smith, Deductions by Corporations of Expenses of Litigation in Their Defense of Alleged Anti-Trust Violations, 8 ANn. Inst. ON FED. TAXation 646-55, esp. $651-53$ (1950).

224. Union Investment Company, 21 T.C. No. 74 (1954), acq., Curr. Bull. No. 27, p. 4 (July 6, 1954).

225. G.C.M. 24377, 1944 Cum. Bull. 93.

226. Smith, supra note 223 , at 653 , suggests other limits on the apparently broad disallowance in this ruling.

227. See text at note 147 supra.

228. See text at note 148 supra.

229. Lomas \& Nettleton Co. v. United States, 79 F. Supp. 886 (D. Conn. 1948).

230. Suckow Borax Mines Consolidated, Inc., $12 \mathrm{CCH}$ TC MEM. DEC. 786

(1953); Hendrick Ranch Royalties, Inc., 1 CCH TC MEM. DEc. 794 (1943).

231. Hendrick Ranch Royalties, Inc., 1 CCH TC MEM. DEC. 794 (1943).

232. American Factors, Ltd. v. Kanne, 100 F. Supp. 329 (D. Hawaii 1951), on remand from 190 F.2d 155 (9th Cir. 1951); Matson Navigation Co., 24 B.T.A. 14 (1931).

233. O.D. 1117, 5 CuM. BuLr. 121 (1921).

234. See text at note 69 supra.

235. See text at note 75 supra. Cf. Tobacco Products Export Corp., 18 T.C. 1100 (1952) (held: portion of expenses of a partial liquidation attributable to the distribution of corporate assets is deductible).

236. I.R.C. § 165 .

237. Sibley, Lindsay \& Curr Co., 15 T.C. 106 (1950).

238. Doernbecher Mfg. Co., 30 B.T.A. 973 (1934), aff'd on other grounds, 80 F.2d 573 (9th Cir. 1935); Portland Furniture Mfg. Co., 30 B.T.A. 878 (1934), nonacq., XIII-2 CuMs. BuLL. 33 (1934). 
liquidation ${ }^{239}$ are abandoned. The Tax Court has held that it is an ordinary and necessary corporate expense to investigate the tax advantages of operating as a personal service corporation or as a partnership, ${ }^{240}$ but not so to look into the economic advantages of a separate corporation to purchase liquor inventory outside the state. ${ }^{241}$

Both for individuals and for corporations, the Tax Court has allowed a full deduction for relatively small fees for routine work in connection with the business. ${ }^{242}$ In these cases, however, there was no indication that any of the service was for nondeductible items. Where such service is involved, the attorney who does not separately record his time and charges subjects his client to the risk of losing the deduction which might be allowable, since there is no assurance a lump sum fee will be allocated, ${ }^{243}$ and at least puts him to extra argument and possible litigation to justify the deduction of part of the fee. ${ }^{244}$

\section{INVESTMENT AND TAX EXPENSES}

For individuals, and estates, trusts, and partnerships, the 1954 Code ${ }^{245}$ provides a deduction for all ordinary and necessary expenses "(1) for the production or collection of income; (2) for the management, conservation, or maintenance of property held for the production of income; or (3) in connection with the determination, collection, or refund of any tax." The first two items are carried over verbatim from the 1939 Code as amended in $1942 ;{ }^{246}$ the language of the third is wholly new, ${ }^{247}$ but the substance only partly so.

239. Tobacco Prodets Export Corp., 18 T.C. 1100 (1952).

240. Meldrum \& Fewsmith, Inc., 20 T.C. 790 (1953).

241. Helms, Inc., 9 CCH TC MEM. DEc. 1116 (1950). This decision seems to be in hopeless conflict with the later Meldrum case, supra note 240 , and should be considered overruled.

242. San Marco Shop, Inc., 12 CCH TC MEM. DEC., 843 (1953) ("general counsel," although no fee charged for incorporation); Tennessee Valley Leather Co., 8 CCH TC MEM. DEC. 396 (1949) ( $\$ 500$ to attorney "regularly retained"); George Sylvester Viereck, 4 CCH TC MEM. DEC. 1026 (1945) ( $\$ 4700$ "for services rendered $\cdot \dot{i}$ in connection with his business"); Missouri-Kansas Pipe Line Co., $3 \mathrm{CCH}$ TC MEA. DEC. 15 (1944) (ordinary corporate work, corporate reports, meetings of directors, advice to officers and directors on matters generally).

243. Aaron Michaels, 12 T.C. 17 (1949); Sayers F. Harman, 4 T.C. 335 (1944); Arthur Jordan, 12 B.T.A. 423 (1928). See generally the section on Allocation, infra following note 351 .

244. Dwight A. Ward, 20 T.C. 332 (1953) ; Saks \& Co., 20 B.T.A. 1151 (1930), noracq., X-1 CuM. Bult. 92 (1931).

245. I.R.C. $\$ 212$.

246. INT. Rev. CoDE of 1939, $\S 23(\mathrm{a})(2)$, as amended, Revenue Act of 1942, $\S 121,56$ StAT. 819 (1942).

247. See Sen. Rep. No. 1622, 83d Cong., 2d Sess. 34, 218 (1954); H.R. Rep. No. 1337, 83d Cong., 2d Sess. 29, A. 59 (1954). 
Both the 1942 and the 1954 changes reverse victories ${ }^{248}$ won by the Commissioner in the Supreme Court. In 1941 the Court held that the management of investments could not constitute a "trade or business" and that, therefore, the expenses of managing securities were not deductible. ${ }^{249}$ Congress responded in 1942 by creating a deduction for investment expenses. In 1952 the Court denied a deduction for the legal costs of contesting a gift tax deficiency, ${ }^{250}$ but, since income and estate tax litigation costs were deductible, Congress felt it equitable to create a deduction for such costs in connection with "any tax," including federal, state, county or municipal, income, estate, gift, and property. ${ }^{251}$

The expenses deductible under the first two paragraphs of Section 212 do not have to be matched to specific items of annual income. "Income" for this section includes income which may have been received in prior years or may come in future years. ${ }^{252}$ The income need not be recurring; gain on the sale of a single property is included. ${ }^{253}$ If a property is held for investment, the expense of managing or conserving it is fully deductible, "even though there is no likelihood that the property will be sold at a profit or will otherwise be productive of income, ${ }^{254}$ and even though the property is held merely to minimize a loss with respect thereto." ${ }^{255}$ While this is a broad concept of "income," the income must belong to the taxpayer who claims the deduction ${ }^{256}$ and, although the time of realization of the income may be remote, the taxpayer must expect to realize it for himself or in the capacity in which he acts.

248. Higgins v. Commissioner of Int. Rev., 312 U.S. 212 (1941) (aithough a change had been recommended as early as 1938; see Brodsky and McKibben, Deduction of Non-Trade or Non-Business Expenses, 2 TAX L. REv. 39, 40 et seq. (1946)); and Lykes v. United States, 343 U.S. 118 (1952).

249. Higgins v. Commissioner of Int. Rev., 312 U.S. 212 (1941).

250. Lykes v. United States, 343 U.S. 118 (1952).

251. I.R.C. \$212(3), 69. See Sen. Rep. No. 1622, 83d Cong., 2d Sess. 34, 218 (1954); H.R. REP. No. 1337, 83d Cong., 2d Sess. 29, A 59 (1954).

252. U.S. Treas. Reg. $118, \S 39.23$ (a) -15 (b) ; U.S. Treas. $111, \S 29.23$ (a)-15(a) ; T.D. 5196, 1942-2 Cum. BulL. 96, 98; SEN. Rep. No. 1631, 77th Cong., 2d Sess. 87 (1942), 1942-2 CUM. Bull. 504, 570-71; H.R. REP. No. 2333, 77th Cong., 2d Sess. 75 (1942), 1942-2 Cum. Burl. 372, 429.

253. See note 252 supra.

254. See note 252 supra.

255. See note 252 supra, except for H.R. REP. No. 2333.

256. Frederic A. Seidler, 18 T.C. 256, 261 (1952) (cost of unsuccessful effort by trustee and sole remainderman to continue $\$ 200,000$ trust: "Since the property interest was not held by the petitioner for the production of income for himself, petitioner must be denied deduction of the expenses incurred."); Dorothy E. Law, 12 CCH TC MEM. DEC. 1440 (1953). These cases would seem to distinguish between $\$ 212(1)$-allowing expenses of producing income in the distant future, and $\S 212(2)-$ not allowing expenses of management and conservation of property held by the taxpayer currently for another, but which in the future would produce income for the taxpayer himself, 
The broad scope of the deductions permitted under Section 212 is not attributable solely to Congress. The Supreme Court, in 1945,257 cut short the narrow construction imposed by the original Treasury regulations ${ }^{258}$ and lower court decisions. ${ }^{259}$ Under these regulations the Treasury had attempted to restrict the deduction of the expenses for tax advice and those of executors, administrators, and receivers. ${ }^{260}$ From December 1942, when the regulations were issued, until 1945, when the Supreme Court decided Trust of Bingham v. Commissioner of Internal Revenue, ${ }^{261}$ many courts went along with the regulations, particularly in respect of fees for income tax matters. ${ }^{262}$ In the Bingham case, the Court held fully deductible a $\$ 16,400$ fee for unsuccessfully contesting an income tax deficiency asserted against the trust, an $\$ 800$ fee in connection with the payment of a legacy to the University of North Carolina, and $\$ 8,600$ for advice on tax and other problems in the termination of the trust and distribution of the trust properties.

The regulations were promptly liberalized early in $1946 .{ }^{263}$ The amended regulations permit a deduction for "reasonable amounts paid

257. Trust of Bingham v. Commissioner of Int. Rev., 325 U.S. 365 (1945), reversing 145 F.2d 568 (2d Cir. 1944), reversing 2 T.C. 853 (1943). At p. 377: "So far as this Regulation [\$23(a) (2)] purports to deny deduction of litigation expense unless it is to produce income, it is not in conformity with the statute... which provides that in addition to expenses for the production or collection of trust income, expenses of management or conservation of trust property held for the production of income are also deductible."

258. T.D. 5196, 1942-2 CuMr. ButL. 96.

259. Stoddard v. Commissioner of Int. Rev., 141 F.2d 76 (2d Cir. 1944); Hord v. Commissioner of Int. Rev., 143 F.2d 73 (6th Cir. 1944) ; Higgins v. Commissioner of Int. Rev., 143 F.2d 654 (1st Cir. 1944); Davis v. Commissioner of Int. Rev., 151 F.2d 441 (8th Cir. 1945); Commissioner of Int. Rev. v. Kenan, 145 F.2d 568 (2d Cir. 1944).

260. T.D. 5196, 1942-2 Cum. BuLl. 96. The following items were considered non-deductible:

1. The expenses of a decedent's personal representative for

(a) "securing the processes and orders of the court having jurisdiction over the probate of [an] estate,"

(b) "adjusting claims against the estate," or

(c) "distributing the remaining assets to the beneficiaries."

2. The ordinary expenses of receivership or bankruptcy, such as

(a) "fees paid to the attorney for . . . petitioning creditors,"

(b) "fees paid to the appraisers," and

(c) the expenses of the "collection of the assets and their preservation pending ultimate distribution to the parties entitled thereto."

3. Expenditures incurred for the purpose of

(a) "preparing tax returns (except to the extent such returns relate to taxes on property held for the production of income),"

(b) "recovering taxes (other than recoveries required to be included in income)," or

(c) "resisting a proposed additional assessment of taxes (other than taxes on property held for the production of income)."

261. 325 U.S. 365 (1945).

262. See note 259 supra.

263. T.D. 5513, 1946-1 CuM. BuLL. 61. 
or incurred by the fiduciary of an estate or trust on account of administration expenses, including fiduciaries' fees and expenses of litigation." 264 This language now permits an executor or administrator in determining taxable income to deduct statutory fees for regular probate services. $^{285}$ The prohibition against the deduction of receiver's fees was deleted. ${ }^{266}$ The regulations spelled out a deduction for the expenses of determining the liability for taxes upon income, and property taxes on income producing property, although they persisted in denying a deduction for the cost of determining gift taxes, "except to the extent that such expenses are allocable to interest on a refund of gift taxes." 267

Subsequent cases have repeatedly allowed a deduction for the cost of income tax litigation, whether recovering an overpayment, ${ }^{268}$ resisting a deficiency successfully ${ }^{269}$ or unsuccessfully, ${ }^{270}$ defending against transferee liability, ${ }^{271}$ defending a civil fraud charge, though unsuccessfully, ${ }^{272}$ or in attempts to determine and settle the tax liability prior to an indictment and conviction for criminal fraud. ${ }^{273}$ Similarly fees paid either by the executor ${ }^{274}$ or remainderman ${ }^{275}$ in the determination of an estate tax liability are deductible. 15 (b).

264. U.S. Treas. Reg. 118, $\$ 39.23(a)-15$ (i) ; U.S. Treas. Reg. 111, §29.23(a)-

265. Special letter ruling dated Sept. 22, 1947, signed Fred. S. Martin, Acting Deputy Commissioner (IT:P :TR-RFD-5), 5 CCH 1948 FEd. TAX SERV. II 6043.

266. T.D. 5513, 1946-1 CuM. BuLL. 61. Receivers' expenses of petitions, appraisers, collecting and distributing property would now be deductible. Trust of Bingham v. Commissioner of Int. Rev., 325 U.S. 365 (1945); Trustees of Series Q, Group Certificates of New York Title and Mortgage Co., 2 T.C. 990 (1943).

267. This has been changed by the 1954 Code. See text at note 251 supra.

268. Williams v. McGowan, 152 F.2d 570 (2d Cir. 1945) ; Howard E. Cammack, 5 T.C. 467 (1945), acq., 1945 Cum. Bull. 2.

269. James A. Connelly, 6 T.C. 744 (1946) ; Norbert H. Wiesler, 6 T.C. 1148 (1946); Herbert Marshall, 5 T.C. 1032 (1945); Stoddard v. Commissioner of Int. Rev., 152 F.2d 445 (2d Cir. 1945).

270. William Heyman, 6 T.C. 799 (1946); Trust of Bingham v. Commissioner of Int. Rev., 325 U.S. 365 (1945).

271. Charles N. Manning, 3 T.C. 853 (1944), aff'd, 148 F.2d 821 (6th Cir. 1945) ; Philip D. Armour, 6 T.C. 359 (1946) ; National Ass'n of Schools and Publishers, Inc., 7 CCH TC Mem. Dec. 655 (1948).

272. Charles Goodman, 9 CCH TC MEM. DEC. 789 (1950); Greene Motor Co., 5 T.C. 314 (1945) (where compromise included criminal liability).

273. Hymie Schwartz, 22 T.C. No. 91 (1954) (note five judges dissented and quaere what influence the termination of the attorney's employment before trial and conviction had).

274. See note 265 supra.

275. Northern Trust Co. v. Campbell, 211 F.2d 251 (7th Cir. 1954), affirming McKinstry v. Harrison, 4 P-H (1953) FED. TAX SERv. T 72,397 (N.D. I11.) ; cf. Selig v. Allen, 104 F. Supp. 390 (M.D. Ga., 1952), aff'd, 200 F.2d 487 (5th Cir. 1952). The decision in Marion A. Burtbeck, 15 T.C. 642 (1950) seemingly contra, is distinguishable since it was not shown there what part of the fees in a will contest were allocable to resisting inheritance and estate taxes. 


\section{Production or Collection of Income}

The expense, to be deductible, need not relate to the production or collection of income in the current taxable year. ${ }^{278}$ Although there have been no decisions on point, if the expense relates to an attempt to collect specific income, it should make no difference whether the attempt be successful unless its failure may be traced to some fault on the taxpayer's part. ${ }^{277}$ Despite speculation to the contrary, ${ }^{278}$ when there has been an effort to collect income, its failure is immaterial on the question of whether the costs are deductible. This view is based upon the following reasons:

1. The committee reports included in "income," "income which the taxpayer . . . may realize in subsequent taxable years." 279 Administratively, therefore, were the rule that income must be successfully produced or collected, it would be impossible to pass upon the deduction in an audit, if at the time of the audit the success of the effort were still in doubt. ${ }^{280}$

2. Congress in 1942, while using much of the language recommended in 1938 by a Ways and Means Committee subcommittee, rejected the limitation then proposed that the deduction not be in excess of one-half the income collected. This rejection gives rise to the inference that none need be collected. ${ }^{281}$

3. The regulations ${ }^{282}$ would allow a deduction for "expenditures incurred . . . in recovering property . . . which if . . recovered, must be included in income." ${ }^{28 s}$ The words "if recovered" would have no purpose if the deduction depended upon a successful recovery.

276. U.S. Treas. Reg. 118, §39.23(a)-15(b).

277. Commissioner of Int. Rev. v. Josephs, 168 F.2d 233 (8th Cir. 1948) ; Commissioner of Int. Rev. v. Heide, 165 F.2d 699 (2d Cir. 1948). But see the discussion of these cases in text at notes 154 and 219 supra.

278. Note, Deductibility of Non-Business Legal Expenses from Gross Income, 97 U. of PA. L. Rev. 251 (1948).

279. H.R. Rep. No. 2333, 77th Cong., 2d Sess. 75 (1942), 1942-2 Cum. Bull. 372, 429 ; Sen. Rep. No. 1631, 77th Cong., 2d Sess. 87 (1942), 1942-2 CuM. Bull. $504,570-71$.

280. The statute of limitations runs three years after the income tax return is filed. I.R.C. $\$ 6501$ (a). An expense is deductible when paid or incurred. I.R.C. $\S 162$. There is no provision to defer the deduction and use it as a set-off when the income might come in in a subsequent year.

281. See Brodsky and McKibben, Deduction of Non-Trade or Non-Business Expenses, 2 TAX L. REv. 39, 40 n.8, 48 n.47 (1946).

282. U.S. Treas. Reg. 118, §39.23(a)-15(k).

283. Cf. Brodsky and McKibben, supra note 281, at 48 . 
4. To the extent that Sections 23(a)(1) and 23(a)(2) of the 1939 Code were in "pari materia," 284 the result should be the same as in the business expense cases where the deduction is allowed in unsuccessful suits. ${ }^{285}$ The Third Circuit has stated: "Nor is it a requirement that the expenses have been incurred in the production of income, or actually productive of income." ${ }^{286}$

5. While the Tax Court dissenting opinions in the fiduciary surcharge cases ${ }^{287}$ may have turned on failure to collect income, neither court of appeals in reversing adopted the reasoning of the dissent. Judge Learned Hand ${ }^{288}$ flatly refused to subsidize inattentive or delinquent trustees and the Eighth Circuit followed suit. ${ }^{289}$ Also Judge Hand carefully pointed out that his decision did not turn on any difference between the "income" and the "management" paragraphs of Section 23 (a) (2), ${ }^{290}$ and lack of success in "management" suits does not spoil the deduction of their costs. ${ }^{291}$

6. Finally, the Supreme Court did not deny a deduction for election expenses on the ground that the candidate lost. ${ }^{292}$ Justice Black and three others would have allowed the deduction squarely as an expense for the production or collection of income. ${ }^{293}$

Although the regulations ${ }^{294}$ mention only fees for collecting rents and interest, the decisions are clear that fees are fully deductible for the collection of salaries, ${ }^{295}$ bonus, ${ }^{296}$ commissions, ${ }^{297}$ dividends and interest, ${ }^{298}$ royalties (where title is not in issue), ${ }^{299}$ taxable alimony, ${ }^{300}$

284. Trust of Bingham v. Commissioner of Int. Rev., 325 U.S. 365 (1945).

285. Udolpho Wolfe Co., 15 B.T.A. 485 (1929), acq., VIII-2 CUM. BuLL. 57;

E. L. Potter, 20 B.T.A. 252 (1930), nonacq., X-1 CUM. BulL. 90 (1931).

286. Urquhart v. Commissioner of Int. Rev., 215 F.2d 17 (3d Cir. 1954).

287. Julius A. Heide, 8 T.C. 314 (1947); Hyman Y. Josephs, 8 T.C. 583 (1947).

288. Commissioner of Int. Rev. v. Heide, 165 F.2d 699, 701 (2d Cir. 1948).

289. Commissioner of Int. Rev. v. Josephs, 168 F.2d 233 (8th Cir. 1948), cert. denied, 335 U.S. 871 (1948).

290. Commissioner of Int. Rev. v. Heide, 165 F.2d 699, 701 (2d Cir. 1948).

291. Trust of Bingham v. Commissioner of Int. Rev., 325 U.S. 365 (1945);

William Heyman, 6 T.C. 799 (1946) ; Carl W. Braznell, 16 T.C. 503 (1951).

292. McDonald v. Commissioner of Int. Rev., 323 U.S. 57 (1944).

293. See Brodsky and McKibben, supra note 281, at 48; Nahstoll, Non-Trade and

Non-Business Expense Deductions, 46 MICH. L. REv. 1015, 1020-23 (1948).

294. U.S. Treas. Reg. 118, \$39.23(a)-15(k) (1953).

295. E. L. Potter, 20 B.T.A. 252 (1930), nonacq., $\dot{X}-1$ Cum. BulL. 90 (1931).

296. Joseph Frank, 22 T.C. No. 113 (1954).

297. Annie Laurie Crawford, 5 T.C. 91 (1945).

298. Virginia Hansen Vincent, 18 T.C. 339 (1952).

299. Jack Rosenzweig, 1 T.C. 24 (1942), acq., 1943 Cum. Butr. 19; Raymond

M. Hessert, 1 CCH TC MEM. DEC. 932 (1943); Pierce Estates, Inc., 3 T.C. 875 (1944), nonacq., 1944 Cum. Bull. 51 ; Urquhart v. Commissioner of Int. Rev., 215 F.2d 17 (3d Cir. 1954).

300. T.D. 5889, 1952-1 CuM. Bulz. 31; Barbara B. LeMond, 13 T.C. 670 (1949);

Elsie B. Gale, 13 T.C. 661 (1949). This represents a reversal of I.T. 3856, 1947-1

CuM. Buxx. 23, which considered the expense "personal." 
trust income, ${ }^{301}$ sweepstakes winnings, ${ }^{302}$ and damages for breach of a contract to sell. . $^{303}$

\section{Collecting the Proceeds from the Sale of Property}

When lawyers' fees arise from litigation relating to the sale of property, even now it is uncertain whether they are merely direct charges to the profit or loss on the particular sale, like brokers' commissions on the sale of stock, ${ }^{304}$ or are fully deductible as a fee paid for the production of income or management of property held for the production of income. The distinction is important because, where long term capital gain or capital loss results from the sale, if the litigation costs are a direct charge against the proceeds the tax benefit is cut to one-half or, if the capital loss is not deductible, even to zero. ${ }^{305} \mathrm{Un}$ til the law is clarified, by statute or decision, such attorneys' fees should be claimed in full as a deduction. ${ }^{306}$

In commenting on the 1942 amendment which created a deduction against gross income for expenses "for the production or collection of income," 307 both the House and Senate reports on the bill state that, "The term 'income' for this purpose . . . is not confined to recurring income but applies as well to gain from the disposition of property." 308 It is immaterial that such gain may be capital gain; the deduction is an ordinary deduction in the Fifth ${ }^{809}$ and Ninth ${ }^{310}$ Circuits, but in the Eighth it is an offset against the proceeds of sale..$^{311}$

301. Mary deF. Harrison Geary, 9 T.C. 8 (1947) ; Stella Elkins Tyler, 6 T.C. 135 (1946).

302. Harry Kanelos, 2 CCH TC MEM. DEC. 806 (1943).

303. Joseph G. Hitner, 1 CCH TC MEM. Dec. 596 (1943).

304. Spreckels v. Commissioner of Int. Rev., 315 U.S. 626 (1942) ; G.C.M. 15430, XIV-2 CuM. BuLL. 59 (1935).

305. A capital loss is nondeductible if it exceeds capital gains in the case of corporations or exceeds capital gains by more than $\$ 1000$ per year for individuals for the current year and the five succeeding carry-over years.

306. Support for this claim is found in Agnes Pyne Coke, 17 T.C. 403 (1951), aff'd per curiam, 201 F.2d 742 (5th Cir. 1953) ; Walter S. Heller, 2 T.C. 371 (1943), aff'd, 147 F.2d 376 (9th Cir. 1945), cert. denied, 325 U.S. 868 (1945) ; cf. McDonald v. Commissioner of Int. Rev., 323 U.S. 57, 66-67 (1944) (dissenting opinion).

307. Int. REv. CoDe of 1939, $\$ 23$ (a) (2), as amended, 56 Stat. 819 , now I.R.C. $\S 212(1)$.

308. H.R. REP. No. 2333, 77th Cong., 2d Sess. 75 (1942), 1942-2 Cum. Bull. 372, 430; SeN. Rep. No. 1631, 77th Cong., 2d Sess. 87 (1942), 1942-2 CuM. Bull. 504,571 .

309. Commissioner of Int. Rev. v. Coke, 201 F.2d 742 (5th Cir. 1953), affirming per curiam 17 T.C. 403 (1951) (deduction of legal fees in collecting the proceeds of stock sold at a capital gain in the settlement of a separation dispute between husband and wife).

310. Heller v. Commissioner of Int. Rev., 147 F.2d 376 (9th Cir. 1945), cert. denied, 325 U.S. 868 (1945) (legal costs of appraising a dissenter's stock in a proposed merger).

311. Davis v. Comissioner of Int. Rev., 151 F.2d 441 (8th Cir. 1945), cert. denied, 327 U.S. 783 (1946) (straight commission in the ordinary sale of securities). 
Of the five Tax Court decisions where the issue is clearly seen, three take the ordinary deduction view, ${ }^{\mathbf{3 1 2}}$ two treat such expense as a direct offset to the proceeds. ${ }^{313}$ In addition, there are several Tax Court decisions where the language, without any analysis in the opinion, would sustain the full deduction ${ }^{\mathbf{3 1 4}}$ and several, again without reasoning or cited authority, which simply state that sales expense is set off against capital gain. ${ }^{315}$

The argument for the offset treatment ${ }^{316}$ is built upon the language in the committee reports that "[a] deduction under this section is subject, except for the requirement of being incurred in connection with a trade or business, to all the restrictions and limitations that apply in the case of the deduction under section 23 (a)(1)(A) of an expense paid or incurred in carrying on any trade or business." 317 Then, by reference to the pari materia language in the Bingham case, ${ }^{318}$ forgetting that the Supreme Court had limited that decision to interpretation only of the management of property paragraph of the 1942 amendment, ${ }^{319}$ legal expenses not deductible to a business are not deductible to an individual. ${ }^{320}$ Spreckels $v$. Commissioner of Internal Revenue holds that commissions on the sale of stock "have been 'consistently treated . . . not as items of current expense, but as . . . deductions from the proceeds of sale," "321 and are, therefore, not a business expense deduction.

The "restrictions and limitations" language of the legislative reports can be given adequate scope by limiting it to the statutory restrictions, such as that the expense be ordinary, necessary, reasonable, not

312. Agnes Pyne Coke, 17 T.C. 403, 408 (1951); Robert D. L. Gardiner, 4 CCH TC MEM. DEC. 689 (1945); Walter S. Heller, 2 T.C. 371 (1943).

313. H. C. Naylor, 17 T.C. 959 (1951) ; Don A. Davis, 4 T.C. 329 (1944).

314. Brad Love Sneed, 12 CCH TC MEM. Dec. 711 (1953) ; Truman H. Newberry, 4 CCH TC MEM. DEc. 576 (1945); see Charles N. Manning, 3 T.C. 853, 874 (1944); Margery K. Megargel, 3 T.C. 238, 251 (1944) (where although the language of the opinion was broad, petitioners own attorneys submitted a Rule 50 computation treating the fees as an offset to sales proceeds, thus cutting the deduction in half) ; James S. Floyd, 2 CCH TC MEM. DEc. 776 (1943); Raymond M. Hessert, 1 CCH TC MeM. DeC. 932 (1943).

315. Joseph Frank, 22 T.C. No. 113 (1954); Dwight A. Ward, 20 T.C. 332 (1953); William Justin Petit, 8 T.C. 228 (1947).

316. Davis v. Commissioner of Int. Rev., 151 F.2d 441, 443 (8th Cir. 1945), cert. denied, 327 U.S. 783 (1946).

317. H.R. Rep. No. 2333, 77th Cong., $2 d$ Sess. 75 (1942), 1942-2 CuM. Buld. 372, 430 ; Sen. Rep. No. 1631, 77th Cong., 2d Sess. 88 (1942), 1942-2 Cum. Bull. $504,571$. (1945).

318. Trust of Bingham v. Commissioner of Int. Rev., 325 U.S. 365, 373-74

319. Id. at 371 ; cf. Julius A. Heide, 8 T.C. 314, 321 (1947) (dissenting opinion); Hyman Y. Josephs, 8 T.C. 583, 589-91 (1947) (dissenting opinion).

320. Davis v. Commissioner of Int. Rev., 151 F.2d 441, 443 (8th Cir. 1945), cert. denied, 327 U.S. 783 (1946).

321. 315 U.S. 626,629 (1942). 
personal, not a capital expenditure to increase the value of any property or estate, and not allocable to tax exempt income. Neither the Treasury G.C.M. nor the Supreme Court opinion in the Spreckels case calls sales expenses "capital expenditures." ${ }^{22}$ The Court simply held they were not "business expenses." Therefore, not being a business expense in the first place, they cannot be within the meaning of "restrictions and limitations" on the deduction of business expenses.

Whichever way the next court of appeals to face the issue may decide, whether allowing a full deduction under the statutory language "for the production and collection of income" and the express indication in the committee reports that "income" meant gain on the sale of property, or disallowance relying on the general language in the same reports and a feeling that Congress did not intend what it said, the Supreme Court should recognize the conflict and eliminate the confusion.

Apart from the problem of the proper treatment of attorneys' fees which, like brokers' commissions, may be considered "selling expenses," Naylor v. Commissioner of Internal Revenue ${ }^{323}$ indicates one precaution the practicing attorney should take. When negotiating a contract for the seller, once the contract terms have been settled and the agreement has become binding so that an action for damages or specific enforcement would lie, the attorney should close his books and set a fee. The fee for any further services in the nature of enforcing the agreement and collecting income is fully deductible.

\section{Fees for Property Management}

Despite the Treasury's early efforts to limit the non-business deduction authorized by the 1942 amendments to expenses of producing or collecting income, ${ }^{324}$ in 1945 the Bingham decision ${ }^{325}$ underlined the sub-section allowing a deduction for the expenses "for the management, conservation or maintenance of property held for the production of income." ${ }^{326}$ Most legal fees are allowed as expenses of "management," though in one or two cases the opinions have referred only to "conservation or maintenance." 327

322. G.C.M. 15430, XIV-2 CuMr. BuLL. 59 (1935) ; Spreckels v. Commissioner of Int. Rev., 315 U.S. 626 (1942).

323. 203 F.2d 346 (5th Cir. 1953).

324. T.D. 5196, 1942-2 Cum. Bull. 96. See text at note 260 and note 260 supra.

325. Trust of Bingham v. Commissioner of Int. Rev., 325 U.S. 365 (1945).

326. I.R.C. $\S 212(2)$.

327. Baer v. Commissioner of Int. Rev., 196 F.2d 646 (8th Cir. 1952); James A. Connelly, 6 T.C. 744 (1946); Truman H. Newberry, 4 CCH TC Mas. DEc. 576 (1945). 
The "property" managed may be in almost any form productive of income, although an unliquidated claim against a guardian and his surety ${ }^{328}$ and a claim under an agreement restricting the sale of stock $^{329}$ have failed to qualify. The taxpayer claiming the deduction must have legal title ${ }^{330}$ or an equitable income interest ${ }^{331}$ in the property.

An individual may deduct fees for legal advice and investment counsel as to investments in securities ${ }^{\mathbf{3 3 2}}$ and real estate, and as to the management of corporations ${ }^{333}$ or trusts ${ }^{334}$ in which he owns an interest. Similarly, fees paid for advice in "conserving and maintaining" a block of stock which gave the taxpayer control of a corporation, ${ }^{335}$ or in defense of damage suits for refusing to carry out a contract to sell real estate ${ }^{336}$ or stock ${ }^{337}$ are deductible. Note that in these cases the defendant's title to the property was not considered in issue. Likewise title to property is not considered in issue when a trust settlor sues to set the transfer aside. His legal fees are deductible as expenses of conservation and management..$^{338}$

Individuals often engage an attorney for "estate planning," but he should be cautious not to bill for the work as a unit; ${ }^{339}$ only some of the services involved are deductible. The problem was squarely presented in Nancy Reynolds Bagley, ${ }^{340}$ the sole case on all fours.

A member of the R. J. Reynolds family, Mrs. Bagley undertook extensive estate planning. She was allowed to deduct the fee paid to a firm of "estate planners" who made a survey of her properties and proposed a plan of reinvestment including inter vivos and testamentary trusts and insurance. Her attorneys' fees were held deductible for advice on (1) the advisability of purchasing interest-bearing securties, (2) the making of interest-bearing loans to corporate officers to protect her investment in the family corporation, and (3) the merit of

328. Helvering v. Stormfeltz, 142 F.2d 982 (8th Cir. 1944).

329. Dorothy E. Law, 12 CCH TC Mem. DEC. 1440 (1953).

330. Compare Baer v. Commissioner of Int. Rev., 196 F.2d 646 (8th Cir. 1952), with Dorothy E. Law, 12 CCH TC MEM. DEC. 1440 (1953).

331. Compare Herman W. Fletcher, $10 \mathrm{CCH}$ TC MEM. Dec. 793 (1951), with Frederic A. Seidler, 18 T.C. 256 (1952), or Wayne Henderson, 11 CCH TC MEM. DEC. 419 (1952).

332. Winifred L. Milner Estate, 1 CCH TC MEM. Dec. 513 (1943).

333. Edward G. Acheson, Jr., 1 CCH TC MEM. Dec. 877 (1943).

334. Herman W. Fletcher, $10 \mathrm{CCH}$ TC MEMr. DEc. 793 (1951).

335. Baer v. Commissioner of Int. Rev., 196 F.2d 646 (8th Cir. 1952).

336. Carl W. Braznell, 16 T.C. 503 (1951).

337. William P. Toms, 5 CCH TC MEM. Dec. 183 (1946).

338. William J. Garland, 2 CCH TC MEM. Dec. 419 (1943).

339. See Section on Allocation infra following note 351 .

340. 8 T.C. 130 (1947), acq., 1947-1 Cum. Bull. 1. 
plans offered her by investment counsel for the rearrangement and reinvestment of her income-producing property.

At the same time, the Tax Court held attorneys' fees not deductible for (1) advice as to the nature and type of securities and cash which should be set aside from her property to form the principal of the trust for her daughter and for (2) the release of powers of appointment over a trust, in which she was the life beneficiary, which in no way affected her income but only assured her children of receiving the property after her death. Other nondeductible estate planning services are the writing of a will ${ }^{341}$ and the legal services in connection with the making of gifts. 342 A lump sum statement, therefore, for "estate planning" will invite at least an arbitrary allocation by the revenue agent leaning heavily on the value of nondeductible services.

While several opinions have intimated that, in the application of the management provisions, the interposition of a trustee makes no difference, ${ }^{343}$ the courts seem to have been more liberal in allowing deductions for expenses incurred by trustees than for expenses incurred by individuals. The trustee's or executor's activity is considered analogous to a business. ${ }^{344} \mathrm{He}$ is allowed to deduct the costs of collecting income due his decedent, even though it is not taxable to the estate. ${ }^{345}$ $\mathrm{He}$ can deduct the costs of distributing income-producing property, ${ }^{346}$ and guardians' fees paid for incompetents, minors and unborn interests, ${ }^{347}$ although such a deduction would be denied an individual. ${ }^{348}$ This same business conduct concept with its attendant liberality extends to other fiduciaries, such as incompetents', committees, ${ }^{349}$ guardians for minors, ${ }^{350}$ and receivers in bankruptcy. ${ }^{351}$

341. Estate of Helen S. Pennell, 4 B.T.A. 1039 (1926).

342. Lykes v. United States, 343 U.S. 118 (1952).

343. Williams v. McGowan, 152 F.2d 570, 571 (2d Cir. 1945); Howard E. Cammack, 5 T.C. 467,470 (1945).

344. Trust of Bingham v. Commissioner of Int. Rev., 325 U.S. 365, 374 (1945).

345. Commissioner of Int. Rev. v. Goldberger's Estate, 213 F.2d 78 (3d Cir. 1954); James H. Knox Trust, 4 T.C. 258 (1944).

346. Trust of Bingham v. Commissioner of Int. Rev., 325 U.S. 365 (1945).

347. Amy DuPuy McHenry, 6 CCH TC MEM. DEc. 1027 (1947).

348. Cf. Thomas A. Kane, $6 \mathrm{CCH}$ TC MEM. Dec. 222 (1947) (recovery of stock); Lykes v. United States, 343 U.S. 118 (1952) (costs of giving away income producing property); Dorothy E. Law, 12 CCH TC MEM. DEC. 1440 (1953) (legal fees to protect another's income producing property).

349. Estate of Elsie Weil, 13 CCH TC MEM. DEc. 653 (1954); Kohnstamm v. Pedrick, 153 F.2d 506 (2d Cir. 1945).

350. Commissioner of Int. Rev. v. Estate of Bartholomew, 151 F.2d 534 (9th Cir. 1945), affirming 4 T.C. 349 (1944) ; Spear v. Gagne, 49 F. Supp. 263 (D.N.H. 1943).

351. Trustee of Series Q, Group Certficates of New York Title and Mortgage Co., 2 T.C. 990 (1943). 


\section{Allocation}

Couple the nondeductibility of fees for some legal services and the deductibility of others in a single cause, with the difficulties in practice of segregating the deductible from the non-deductible items before making entries on office time records, and a knotty problem arises both for the attorney and the courts. When services for a single client are both deductible and nondeductible, how should the fee be allocated?

The regulations give ample justification for the division of a fee, allocating part to deductible expense and part to non-deductible services. ${ }^{352}$ The most defensible method of allocation is direct tracing based upon time records which show the subject matter on which the work is done, giving proper weight, however, to the other factors relevant in setting the fee. ${ }^{353}$ Since the fee is not based solely on time and labor in most cases, the billing attorney's own allocation of his fee among the services should be entitled to great weight. ${ }^{354}$ Certainly deductible and nondeductible items should be individually priced if they are included in a single itemized statement. ${ }^{355}$

When the services are rendered on a retainer basis or the billing attorney has neglected to value the services individually even though itemizing them, an allocation made by the courts to allow some deductions is usually either (1) in direct proportion to the amounts recovered or claimed, or (2) on the basis of the number of issues involved, or (3) the court will "make as close an approximation as it can, bearing heavily if it chooses upon the taxpayer whose inexactitude is of his own making" ${ }^{356}$ (or his attorney's). Even so, there are judges who will simply deny any deduction for failure of proof if the problem of allocation presents a hurdle. ${ }^{357}$ As the Commissioner himself at least once in the regulations ${ }^{358}$ established a precedent, the philosophy of which unfortunately his representatives do not always accept, it is

352. U.S. Treas. Reg. 118, $\$ 39.23(\mathrm{a})-15(\mathrm{k})$ (1953), specifically allows a deduction for the portion of a fee "properly allocable" to accrued rents, and to interest on a gift tax refund. U.S. Treas. Reg. 118, $\$ 39.24$ (a) -4 (a), 39.24(a) -4 (b) (2) (1953), require an allocation of expenses between taxable and tax exempt income. 1937).

353. Canons of Professional Ethics, Canon 12 (A.B.A. 1908, as amended,

354. Note that it was not questioned in Trust of Bingham, 2 T.C. 853,856 (1943); Nancy Reynolds Bagley, 8 T.C. 130 (1947), acq., 1947-1 Cum. BuLL. 1; Herman W. Fletcher, 10 CCH TC MEM. DEC. 793 (1951).

355. A. H. Morse Co., 11 CCH TC MEM. DEc. 1099, 1103 (1952).

356. Cohan v. Commissioner of Int. Rev., 39 F.2d 540, 544 (2d Cir. 1930).

357. E.g., William Justin Petit, 8 T.C. 228, 236 (1947); Cecil B. Highland, 43 B.T.A. 598 (1941), aff'd, 124 F.2d 556 (4th Cir. 1942). For discussion of the conflicting views see Hochschild v. Commissioner of Int. Rev., 161 F.2d 817, 820 (2d Cir. 1947) (dissenting opinion).

358. U.S. Treas. Reg. 118, §39.23(a)-15(k) (1953). 
to be trusted that judges who refuse to allocate will become a declining minority.

The direct proportion, or percentage, theory of allocation is most easily applied where the suit is for principal and interest. To use the Commissioner's own illustration, ${ }^{359}$ a suit before 1954 for refund of gift taxes, the percentage of fee proportionate to the tax recovered was not deductible; that proportionate to the interest was deductible. Often applied, ${ }^{360}$ the rule may be used even if the attorney represents the losing party. ${ }^{361}$ When the court takes the ordinary deduction view of attorneys' fees in the disposition of property, ${ }^{362}$ the fee is divided by reference to the "basis" of the property in relation to the total recovery including capital gain. ${ }^{363}$

Where the fee involves management expense, rather than collection expense, or the amount of income is indeterminate, the percentage allocation cannot be used. This is true in cases of abandoned reorganization or recapitalization plans and corporate liquidations. Here there is apparently a tendency to allocate the fee on the number of issues involved. ${ }^{364}$

Where the court is satisfied some deductible legal expense was incurred, it has called upon its own experience from the usually meager testimony available to "make as close an approximation as it can." This is the doctrine of the famous case of Cohan $v$. Commissioner of Internal Revenue. ${ }^{365}$ Where the revenue agent has already allowed a

359. Ibid.

360. Helvering v. Stormfeltz, 142 F.2d 982 (8th Cir. 1944) (successful surcharge of a guardian, principal $40.82 \%$, interest $59.18 \%$ ); Harold $\mathrm{K}$. Hochschild, 7 T.C. 81 (1946), acq., 1946-2 CuM. BuLL. 3 (successful defense of stock 85\%, interim dividends 15\%) ; Edmunds v. United States, 71 F. Supp. 29 (E.D. Mo. 1947) (principal plus interest on estate tax refund); Specialty Engineering Co., 12 T.C. 1173 (1949), aca. 1950-1 CuM. BuLL. 5 (recovery of value of partnership interest plus interest); Barbara B. LeMond, 13 T.C. 670 (1949) (non-taxable alimony 20\%, taxable alimony 80\%); Kimbrell v. Dallman, 80 F. Supp. 695 (S.D. Ill. 1948) (mineral interest and impounded royalties, showing that percentage depletion reduces the income factor).

361. William A. Falls, 7 T.C. 66 (1946), acq., 1946-2 Cum. BuLI. 2 (unsuccessful defense of patents $6.27 \%$ and past royalties $93.73 \%$ ).

362. See text at note 309 supra.

363. Agnes Pyne Coke, 17 T.C. 403 (1951), aff'd per curiam, 201 F.2d 742 (5th Cir. 1953) (petitioner's stock sold in settlement of community property suit for $\$ 246,560$; basis, $\$ 61,425$; gain, $\$ 185,135$; deductible portion of fee $\$ 185,135 / \$ 246,560$, or $75 \%$ ).

364. Sibley, Lindsay \& Curr Co., 15 T.C. 106 (1950); Tobacco Products Export Corp., 18 T.C. 1100 (1952); cf. E. J. Murray, 21 T.C. 1049 (1954).

365. 39 F.2d 540, 543-44 (2d Cir. 1930), Judge Learned Hand, in commenting on the Board's refusal to allow any entertainment expense: "Absolute certainty in such matters is usually impossible and is not necessary; the Board should make as close an approximation as it can, bearing heavily if it chooses upon the taxpayer whose inexactitude is of his own making. But to allow nothing at all appears to us inconsistent with saying that something was spent." For an exhaustive analysis of the Cohan doctrine, see Gluck, How Cohan Works: Allowance of Business Expense Deductions When No Exact Records Are Kept, 6 RuTGERS L. REv. 375 (1952). 
deduction for some of the fee, there is authority for refusing to apply the rule. ${ }^{368}$

You cannot safely count on the courts to allocate. In many cases they have refused, ${ }^{307}$ even though the taxpayer had recovered substantial amounts of taxable interest in the suit, and the treatment of the entire fee as "capital" was completely to deprive the taxpayer of any tax benefit from the payment. ${ }^{\mathbf{6} 8}$ Moreover, the Tax Court itself has divided sharply on the problem. ${ }^{369}$ Your best defense is to prepare your case in advance-make your own allocation when you send the bill.

\section{ConcLusion}

When in order to pay each $\$ 100$ of nondeductible attorney's fee, corporations must have from $\$ 142$ to $\$ 208$ of pre-tax income and individuals, partnerships and estates must have from $\$ 125$, to $\$ 1,111$, you can be of real service to your clients by insuring that each dollar of deductible fee is clearly identified. Although the client does not usually raise the question until he sees the bill, it should come to your thoughts at the very beginning of your service for him.

The manner of carrying out a settlement of a dispute may affect the deductibility of the fee, and should be kept in mind in the negotiations. When claims are stated in the pleadings, the first step in determining whether your fee is deductible has been taken.

Your work should be planned so that the deductible services can be identified and segregated either in time of performance or in time record descriptions. Arguments with the revenue agent can be avoided if billing is kept sufficiently current so that the work done is clearly in mind, and is described clearly and separately valued on the fee statement.

As we have seen, both court decisions and Congressional amendments over the last fifteen years have widened the area of deductible fees.

366. Frieda Hempel, 11 CCH TC Meas. Dec. 1070 (1952).

367. Midco Oil Corp., 20 T.C. 587 (1953); E. S. Shipp, 12 CCH TC MEM. Dec. 682 (1953); William Justin Petit, 8 T.C. 228 (1947).

368. Mills Estate, Inc. v. Commissioner of Int. Rev., 206 F.2d 244 (2d Cir. 1953); Isaac G. Johnson \& Co. v. United States, 149 F.2d 851 (2d Cir. 1945); cf. William Justin Petit, 8 T.C. 228, 236-37 (1947): In denying the allocation Judge Black said, "There is no warrant in law for this. The attorney fees which petitioner paid to Hill, Morgan \& Bledsoe were for their entire services in the condemnation proceeding and there is no basis for allocating $\$ 8,878.36$ of the fee for the collection of interest. The entire amount paid the attorneys for their services must be treated as capital expenditures." He apparently had not looked at the Commissioner's own regulations.

369. In Midco Oil Corp., 20 T.C. 587 (1953), Judges Opper, Kern, Arundell, Johnson and Tietjens dissented. 
Still some of the confusing problems would be eliminated if the courts or Congress made clear the extent of the allowable deduction for producing capital gain; insisted that there be a reasonable allocation when some deductible amount has certainly been paid; and terminate the nondeductibility of "defense of title" expenses where they are not "to increase the value of any property" over its original value at time of acquisition. 